\title{
The Last 15,000 Years: Climate-Controlled and "Rare-Event"-Triggered/Rise and Fall of Holocene Cultures in the Near/Middle East and in Central Europe-Evidence and Background
}

\author{
Werner Schneider ${ }^{1}$, Elias Salameh ${ }^{2}$ \\ ${ }^{1}$ Im Ziegenförth 15, Braunschweig, Germany \\ ${ }^{2}$ Faculty of Science, University of Jordan, Amman, Jordan \\ Email: salameli@ju.edu.jo
}

Received 5 October 2015; accepted 15 November 2015; published 19 November 2015

Copyright @ 2015 by authors and Scientific Research Publishing Inc.

This work is licensed under the Creative Commons Attribution International License (CC BY). http://creativecommons.org/licenses/by/4.0/

(c) () Open Access

\section{Abstract}

Pushed by the results of a preceding publication on the possibly Quaternary Jebel Waqf as Suwwan Meteorite Crater, Jordan [5], where an amazing coincidence of Rapid Climate Changes (RCCs) with Rise and Fall of Neolithic and Bronze Age Cultures became evident for the Near/Middle East, this paper deals with the same subject, however, relating to the complete Holocene period in the same area and, additionally, in Central Europe as well. By application of modern climatic data [6] comprising isotope analysis $\left(\delta^{18} \mathrm{O},{ }^{14} \mathrm{C},{ }^{10} \mathrm{Be}\right)$, acid and aerosol events, and greenhouse gases $\left(\mathrm{CO}_{2}\right.$, $\mathrm{CH}_{4}$ ) Greenland ice cores as well as other astro-/geophysical and geological parameters, an overwhelming coincidence/relation/interdependence of both natural and cultural evidences becomes obvious throughout the last 15,000 years across the Northern Hemisphere. Apart from solar output and other astrophysical processes, most important climate- and Earth-related parameters are Mega-Volcanism (i.e. Santorini Greece: $\sim 3640$ yr cal. B. P.), Impact Events (i.e. during Mesolithic: $9600 \mathrm{yr}$ cal. B. P), rapid oceanic current change (DO-Events), and Plate Tectonics (possibly Atlantis-Event: $\sim 11,500 \mathrm{yr}$ cal. B.P. = Pleistocene/Holocene boundary). The most essential parameter is a significant temperature change related to more or less restricted latitude realms of the Northern Hemisphere. Thus, glacier advance/retreat controls the mobility of peoples (i.e. Nations' Migration, Teutonic Empires) and the access to ore deposits ( $\mathrm{Au}, \mathrm{Ag}, \mathrm{Cu}, \mathrm{Sn}, \mathrm{Zn}, \mathrm{Pb}, \mathrm{Fe}$ ) located in Alpine Mountain Ranges (i.e. End-Neolithic, Early Bronze Age). Myths like the Gilgamesh Epos and John Apocalypse convincingly reveal realistic contents relating to natural hazards like tsunamis, impact and flooding events. They unmisunderstandably make obvious that Myths may provide 
valuable contributions, especially to Geosciences. Some of the controlling parameters interrelate with others or present a kind of hierarchy: Mega-Volcanism/impact events $\rightarrow$ ejecta $\rightarrow$ wildfires, heat storms $\rightarrow$ cosmic winter, sint winter $\rightarrow$ stop of photosynthesis $\rightarrow$ mass extinction environmental pollution $\rightarrow$ greenhouse effects. Significant events ( 21 cases in total) occurred on i.e.:

- 14,450 yr cal. B.P. (first settling of NTUFIAN CULTURE, Jordan).

- 11,500 yr cal. B.P. Pleistocene/Holocene b. Atlantis-Event, interruption of the ABU HUREYRA CULTURE, Syria).

- $9600 \mathrm{yr}$ cal. B.P. (Tectites of vast distribution indicate impacting, collapse of all NATUFIAN TOWNS in southern Jordan, mass extinction of mammals).

- 8200-8000 yr cal. B.P. (temperature decrease, collapse of Cultures in the Near/Middle East, rise of Cultures in Southern Europe).

- 7100-7000 yr cal. B.P.: Early/Middle Neolithic b. caused by an incisive drought in Central Europe, cannibalism throughout the last 10 years at Herxheim, West-Germany.

- 6400-6200 yr cal. B.P. (Middle/Younger Neolithic b., glacier advance in European Alpine Ranges, AHS (actinolite-hornblende-schist for stone adzes and axes) raw materials export stop from High Balkan Mts. to Central Europe).

- 5000-4200 yr cal. B.P. (End Neolithic/Early Bronze Age in Europe, glacier retreat, access to Alpine ore deposits (Cu!), pre-Gilgamish time, beginning of the OLD EGYPTIAN KINGDOM and MINOAN CULTURE).

- $3640 \mathrm{yr}$ cal. B.P. (Santorini outbreak accompanied by tremendous ejection of pumice ashes and environmental pollution across the Mediterranean, strong influence on Ikhnaton's AMARNA C., HYKSOS INVASION, JEWS' IMMIGRATION Invasion of MERITIME NATIONS along the East Mediterranean Coast, Early Bronze Age Hügelgräber C.b. in Central Europe).

- 350-700 yr cal. B.P. (glacier retreat in the alpine region, NATION'S MIGRATION Rise of TEUTONIC EMPIRES).

- 1100-1250 yr A. D. (Great Temperature Maximum, Mongolian invasions in Asia and Europe, HANSA and MARITIME TOWN'S activities: Venice, Genua, Pisa, Crusaders' ENDEAVORS, starting EAST COLONIZATION, EMPEROR/POPE constellation in Europe). Foundation of one of the largest THERAVADA BUDDISTIC PAGODA FIELDS (BAGAN, MYANMAR) in Asia.

- 1460-1780 yr A. D. ("Little Glaciations", during intercalated temperature rise: RELIGIOUS WARS).

- 1890 until Present (exponential rise of average temperature, Imperialism, dramatic growth of Science and Technology, wars, global environmental pollution, refugee problems, continuous step by step species extinction, increasing global confusion).

Balanced and constructive periods existed through i.e.:

- 7500-7100 yr cal. B.P. (during early Neolithic in Southeast and Central Europe).

- 700-400 yr B. C. ("Achsenzeit" [61] in middle latitudes).

- 600-900 yr A.D. (TANG DYNASTY, Syncretism along Silk Road).

The "Great Temperature Maximum" (1100-1250 A.D.) and the modern temperature rise (since 1890) obviously show activities of Cultures triggered in a "positive" or "negative" sense. They indicate higher thermal energy has to be transformed in activities of different quality as suitable to the geographic position and to physical/spiritual/psychic state of the concerned Cultures and Societies. The results presented underline and reconfirm the postulation of Hoyle and Clube and Napier that Rapid Climate Change and "Rare Events" profoundly control/trigger the behavior of Cultures in relation to definite latitude realms and generate "positive/negative" developments of Cultures and their Religions (see "ACHSENZEIT") according to favorable/bad conditions of life.

\section{Keywords}

Climate, Rare Events, Mega-Volcanism, Impact-Events, Comets Interdependence/Relationship, Myths, Cultures, Holocene, Near/Middle East, Central Europe 


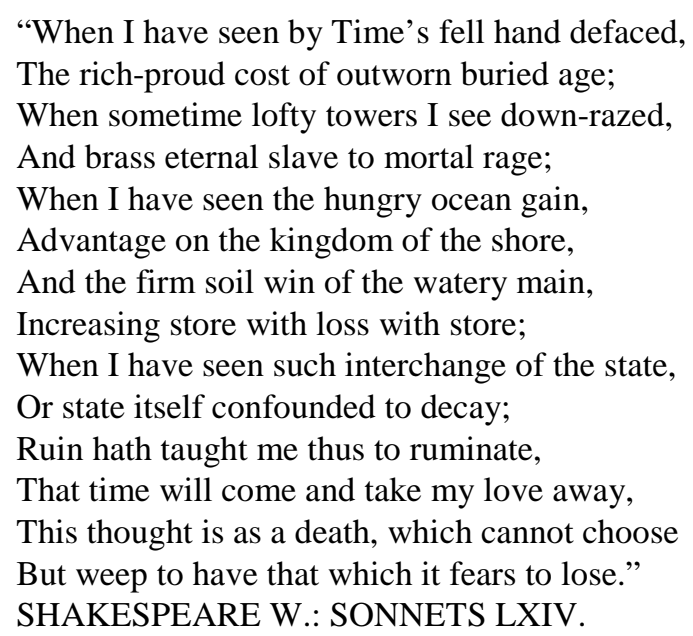

\section{Introduction}

After the discovery of Jebel Waqf as Suwwan Meteorite Crater (JWS), Jordan [1]-[4], some of the authors meanwhile focused on further uncommon geologic and impact-suspicious occurrences in the Near/Middle East [5].

Unfortunately, the age of JWS is still unknown, however, to be expected through the post-Eocene to Early Holocene time-span (Figure 1, Figure 2). Since primary ejecta-fans of the impact site do not reveal any indication on ejected debris' reworking or other post-impact sedimentologic processes like sorting and fluvial transport, it should be stressed that the JWS-Event may have possibly occurred even through Early Holocene (11500-4000 yr cal. B.P.). In this case Mesolithic, Neolithic, and Bronze Age Cultures would have been concerned.

The current paper [5] amazingly underlines a significant coincidence of Rise and Fall of those early settled Farming Cultures in the Near/Middle East with Rapid Climate Change (RCC) and other natural hazards related to the Northern Hemisphere [6].

Furthermore, myths like the GILGAMESH-EPOS [7], the GENESIS (Moses I, II), Old Testament, and JOHN'S APOCALYPSE [8] surprisingly provide realistic contributions for "RARE-EVENT" discussion including the Fall of Early Neolithic Cities in Jordan (NATUFIAN CULTURE).

Consequently, this paper deals with the same intention, namely, coincidence/relation/interchange of RCCs and other natural events with Rise and Fall of Near/Middle East and Central European Cultures through the last 15,000 years.

\section{Methods and Parameters Concerning Rapid Climate Change and "Rare Events"}

"Because of the large number of scientists nowadays and because of the large financial support which they enjoy, uncertain problems mostly have been cleared up already if it were otherwise. So you can be pretty certain that wherever problems resist solution for any appreciable time by an appreciable number of scientists the ideas used for attacking them must be wrong. It is therefore a mistake to have anything to do with popular ideas for solving uncertain issues, and the more respectable may be the more certain it is they are wrong” (F. Hoyle, [9]).

A broad data base for such a challenging subject was published by Mayewski et al., 2004: "Holocene Climate Variability" [6]. Based on 50 globally distributed paleoclimate records including proxies, six RCCs periods are recognized throughout the Holocene (11,500 yr cal. B. P. until Present). Relating to the Northern Hemisphere, most of them are characterized by polar cooling, ice-rafting in North Atlantic, major atmospheric circulation variation, humid climate in the Mediterranean/Levant with temporary flooding episodes, varying glacier advance/retreat in alpine regions of Central Europe, and by droughts in low latitudes as well. The authors give general hints on climate controlled disruptions of civilizations.

The climate-relating parameters used are as follows:

- Carbon dioxide $\left(\mathrm{CO}_{2}\right)$ and methane $\left(\mathrm{CH}_{4}\right)$ in Greenland ice cores, oxygen isotopes $\left(\delta^{18} \mathrm{O}\right)$ in calcareous microfossils (foraminifera) with regard to temperature variation [10] [11] Figure 3(a).

- Radiocarbon data $\left(\delta^{14} \mathrm{C}\right)$ yr cal. B.P. for age determination [12]. 


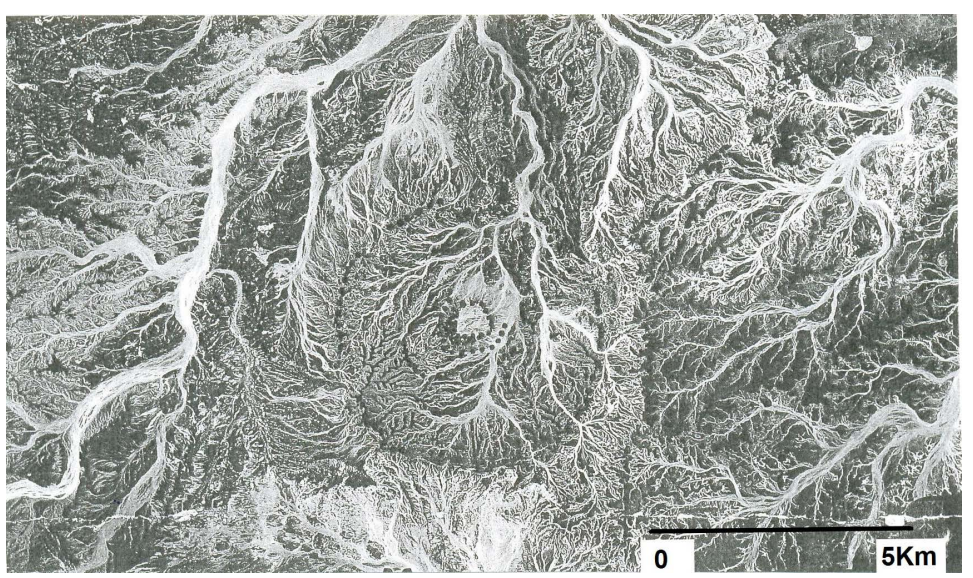

(a)

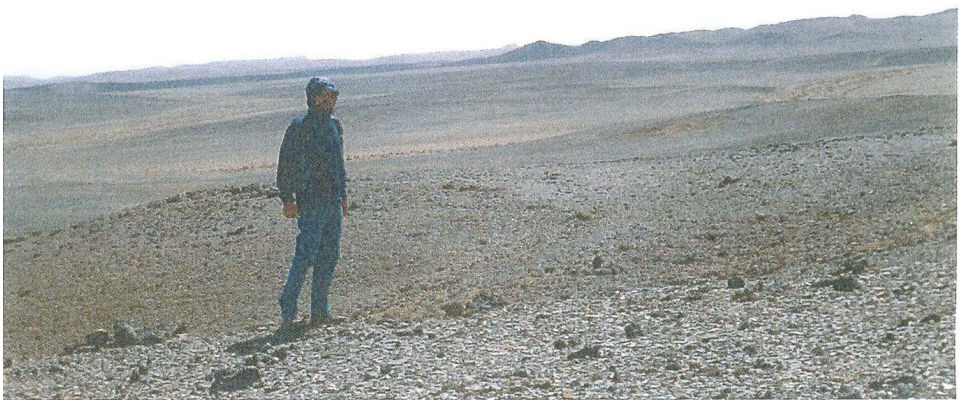

(b)

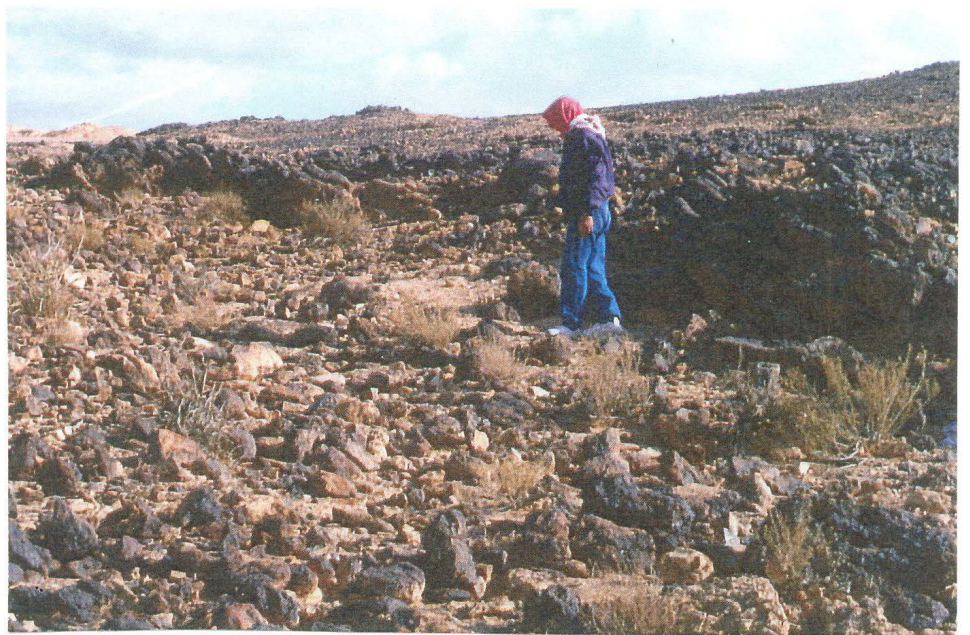

(c)

Figure 1. Jebel Waqf as Suwwan Meteorite Crater and its typical impact features, Eastern Jordanian Desert. Lat. 31.045414, long. 36.807820, elevation 796 meters. (a) The crater exhibits an Inner and Outer Ring Structure, and a Central Uplift. Small wadis show centrifugal and centripetal drainage from the outer rim. Major wadis erode the Holocene clastic fill of the crater northwardly; (b) View from the impact-breccia covered outer rim into the crater, Central Uplift in the right background; (c) Central Uplift exposing dislocated Upper Cretaceous chert beds (black) covered with fall-back impact breccias. 


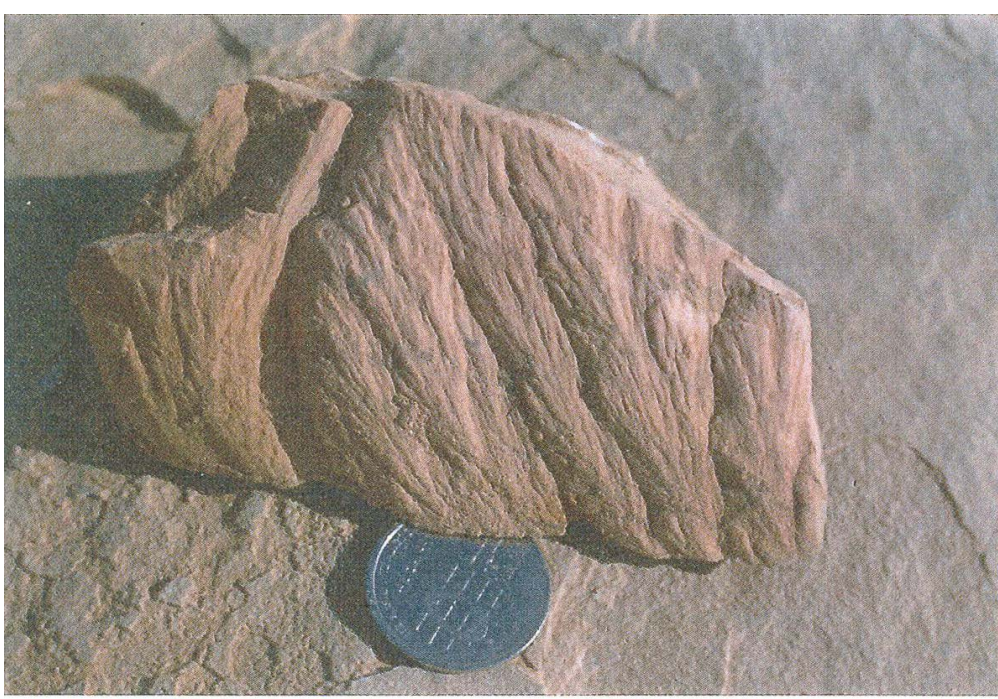

(a)

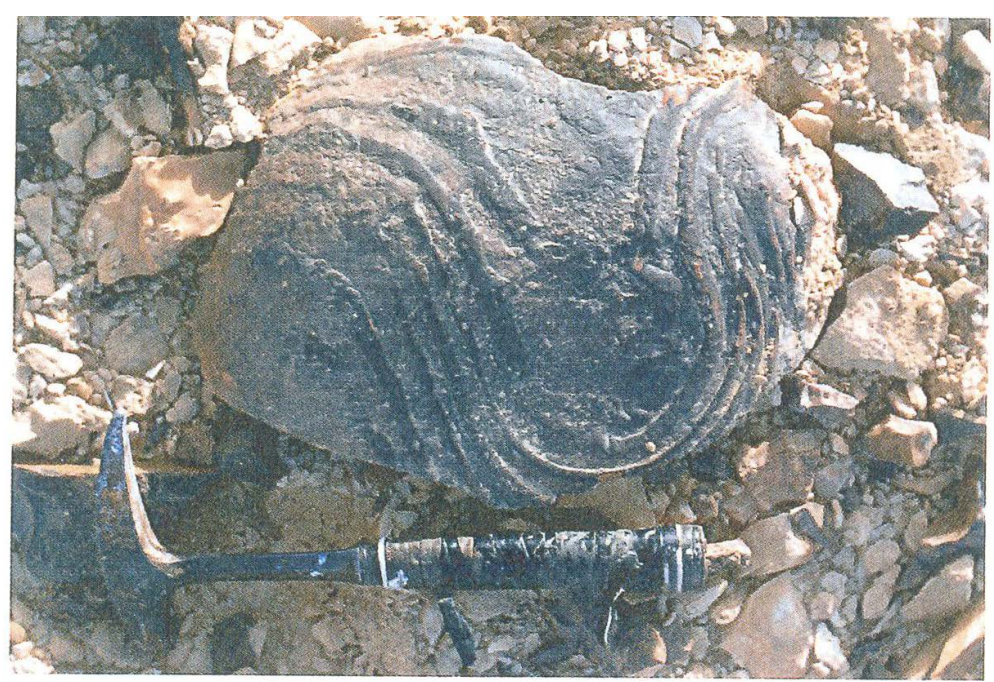

(b)

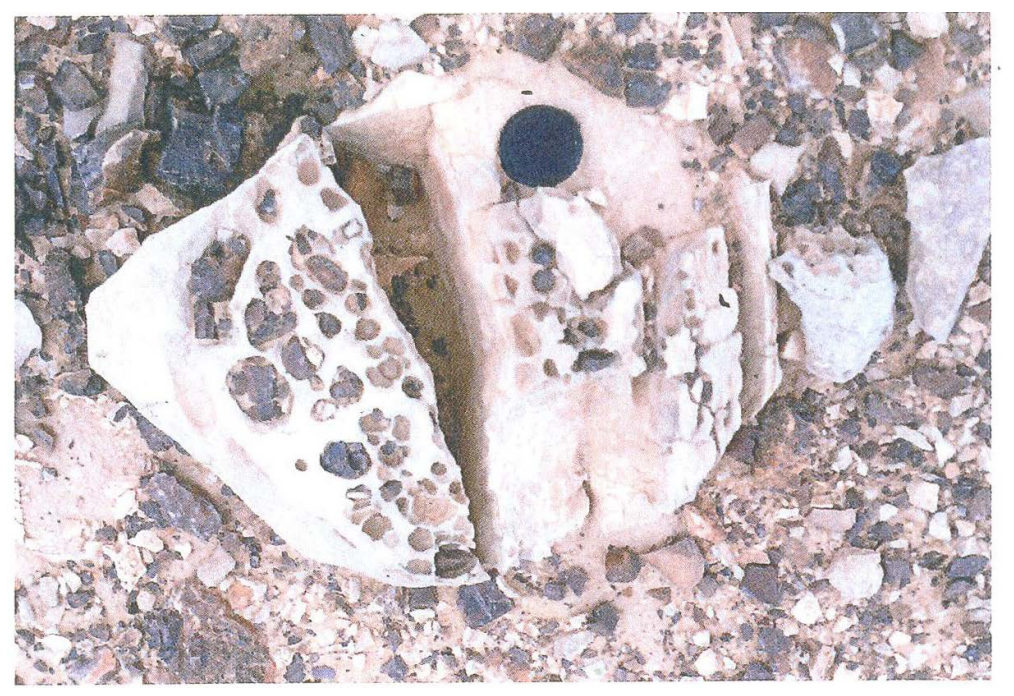

(c) 


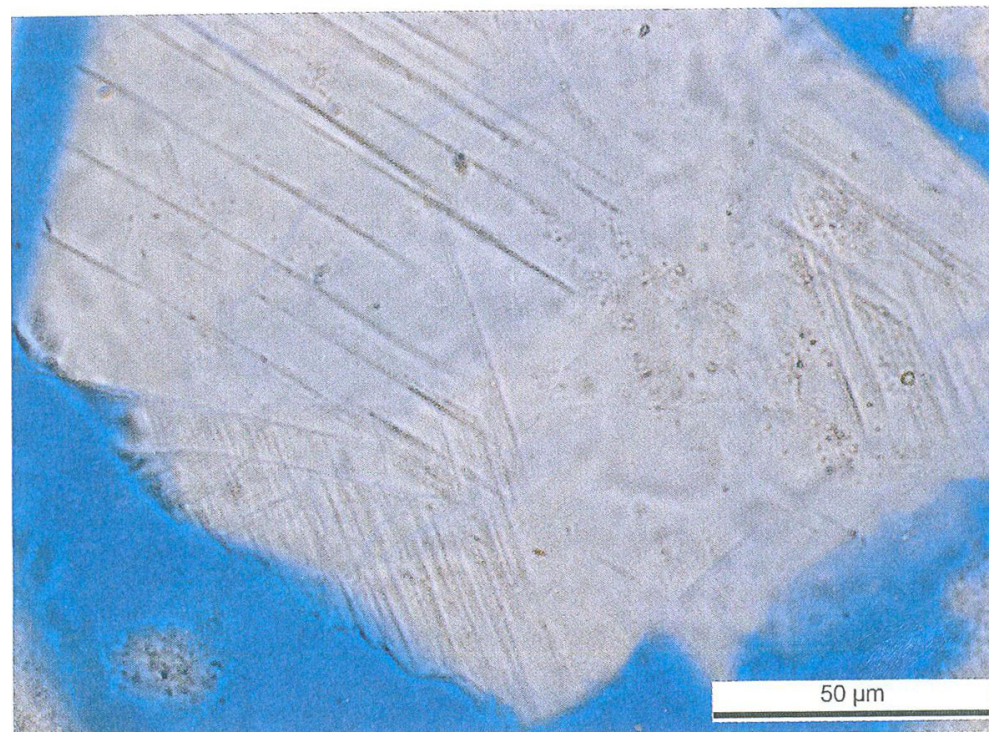

(d)

Figure 2. Impact features of JWS Impact Crater. See also [1]. (a) Typical "shatter cones” (Strahlenkalke) originated in limestones found in between Central Uplift and Inner Ring Structure. (b) Superficially melted ejected chert bomb revealing flow textures of high viscosity (melting temperature $\sim 1714^{\circ} \mathrm{C}$ ). (c) Burnt limestone fragments crashed by highly heated chert ejecta still sticking in the impact holes. Formation temperature at least $\sim 900^{\circ} \mathrm{C}$; (d) Three systems of planar deformation features (PDF) in a quartz grain of Lower Cretaceous sandstones from close to the Central Uplift.

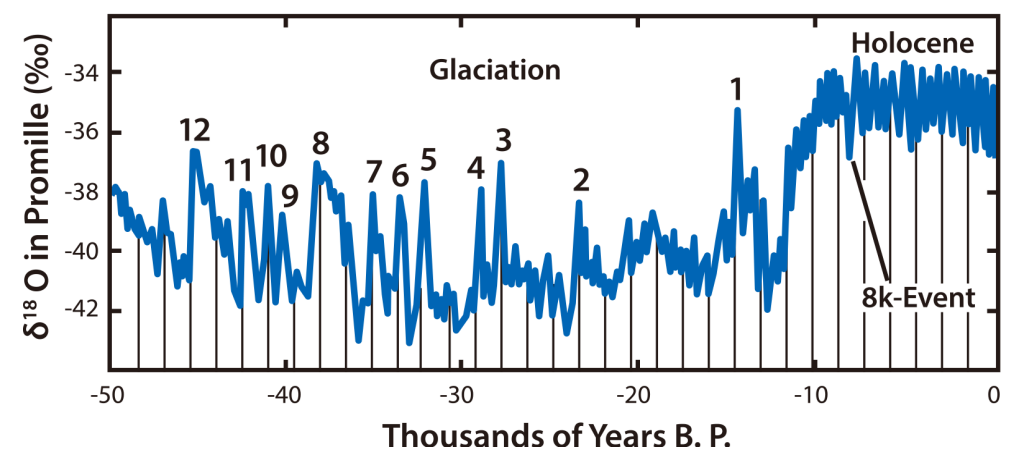

(a)

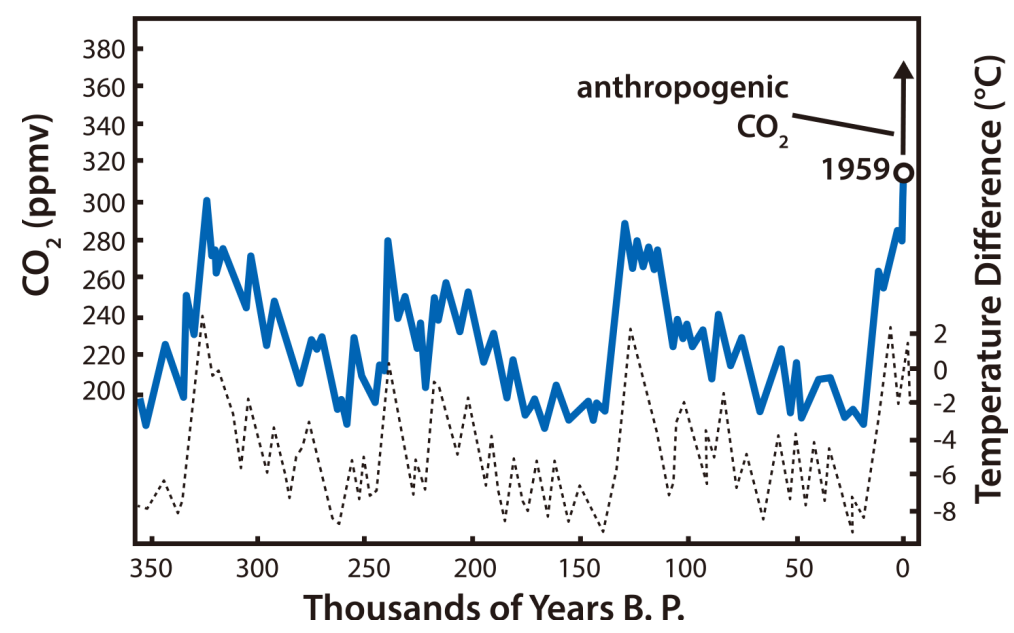

(b) 


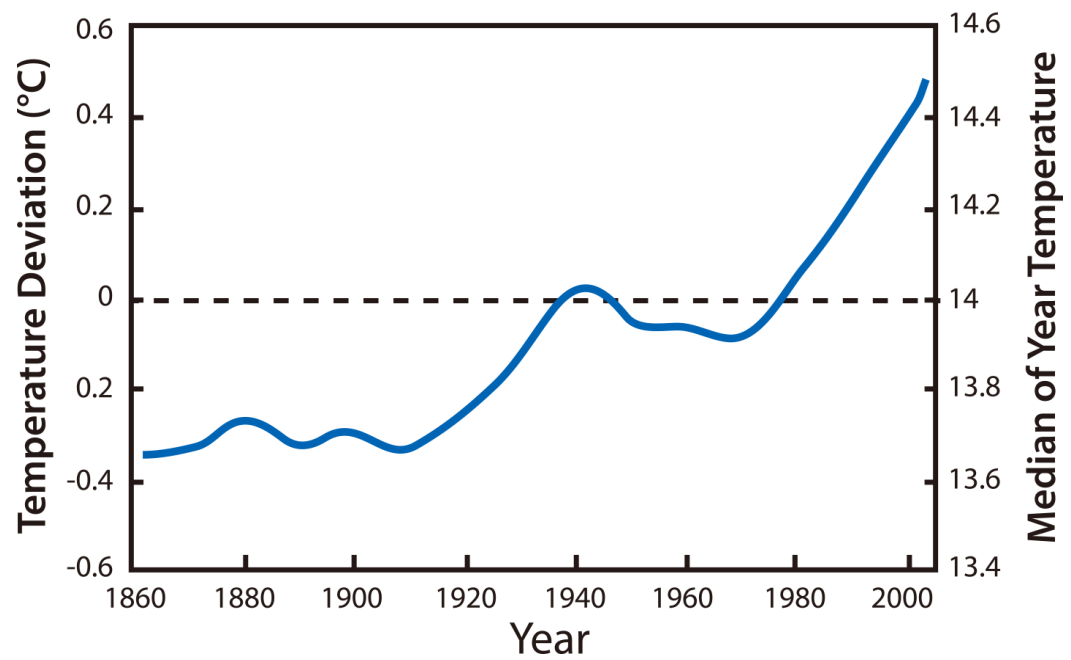

(c)
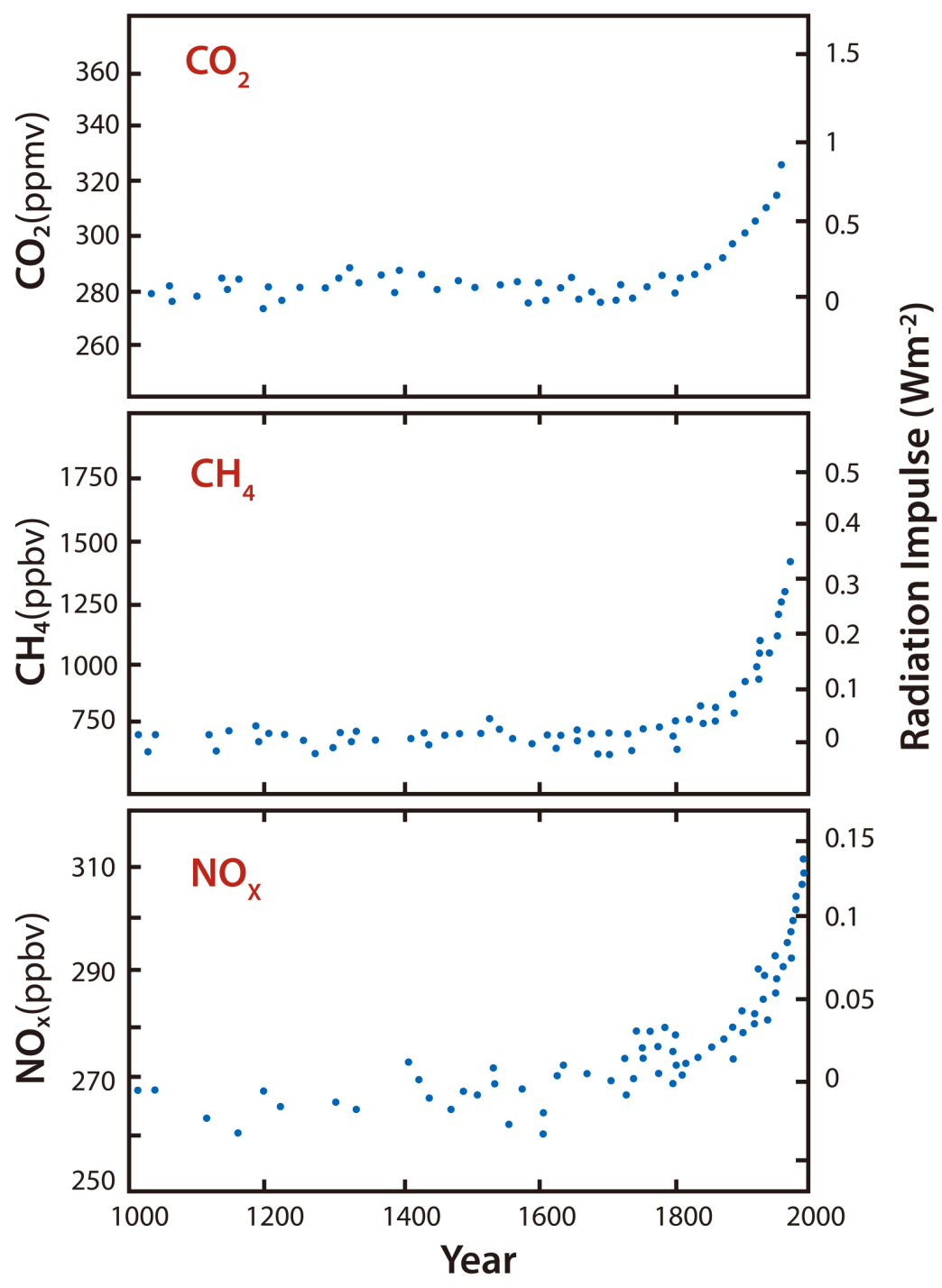

(d) 


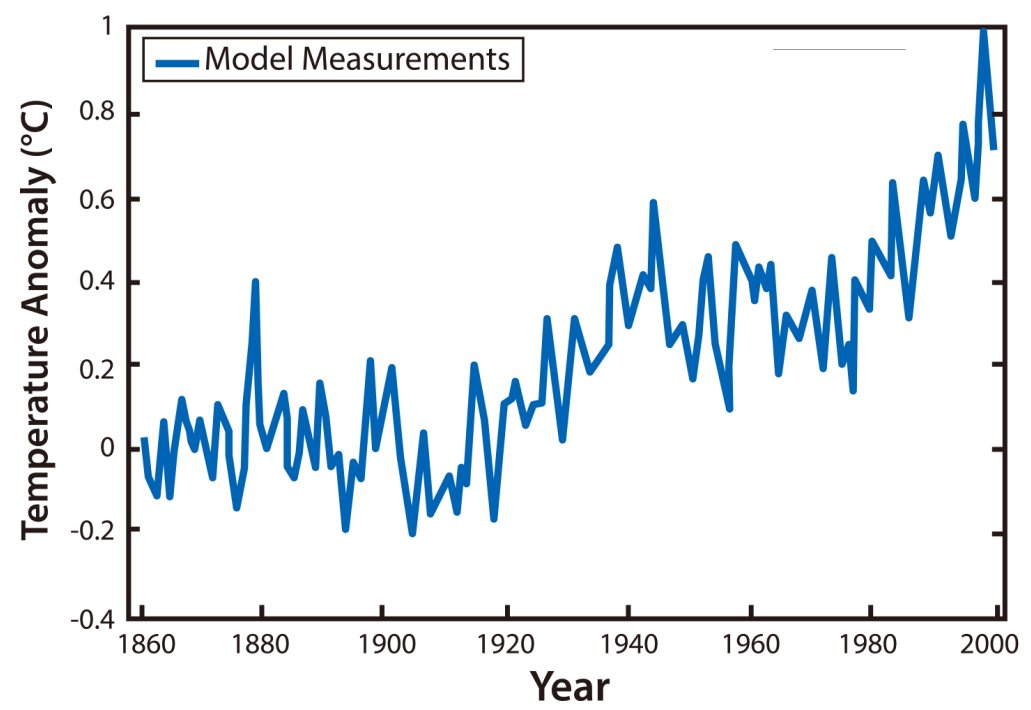

(e)

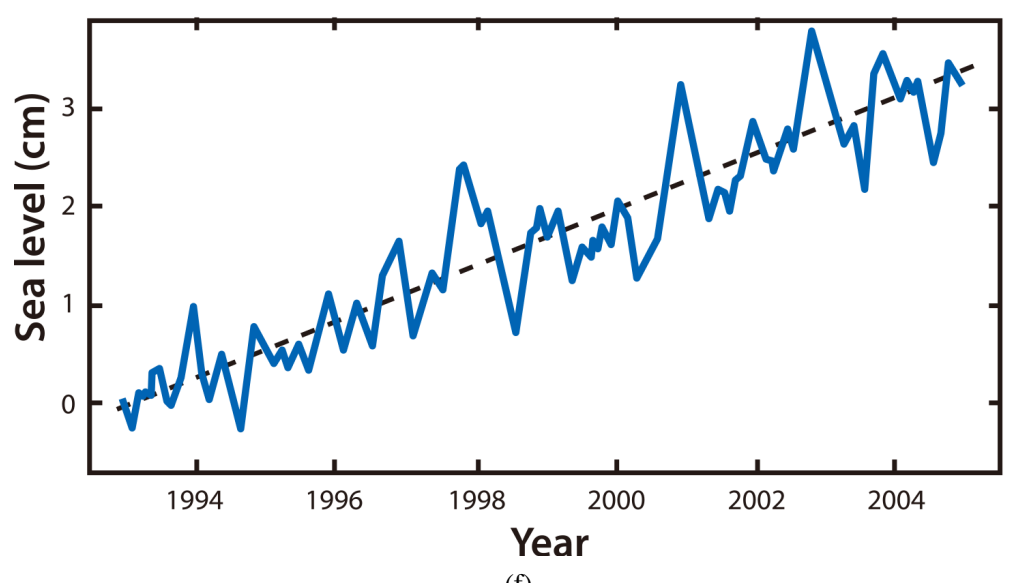

(f)

Figure 3. Climate-relevant data relating to Quaternary, all from Rahmstorf \& Schellnhuber, 2007 [11]. (a) The DansgaardÖschger-Events (DO-Events 0-12) as abrupt warm intervals during Pleistocene measured by $\delta^{18} \mathrm{O}$ isotopes in Greenland ice cores. Note a short cold interval (8k-Event) appearing in Early Holocene ( 8200 yr cal. B.P.) (Rahmstorf, S., Nature, 419, 2002, pp. 207- 241). (b) Glaciation cycles through Pleistocene ascertained by $\mathrm{CO}_{2}$ (black curve) and temperature (grey curve) in the Wostok ice core, Antarctic. Note anthropogenetically caused temperature increase since the mid 20th Century (Petit, J.R. et al., Nature, 399, 1999, pp. 429-436). (c) Globally measured temperature from Meteorologic Stations (1861-2004). Yearly values (grey), flattened curve over 11 years, Hadley Centre. (d) Green House gases $\left(\mathrm{CO}_{2} \mathrm{Ppmv}_{\mathrm{C}} \mathrm{CH}_{4}, \mathrm{NO}_{\mathrm{x}} \mathrm{Ppbv}_{\text {) and }}\right.$ their radiation effect $\left(\mathrm{Watt} / \mathrm{m}^{2}\right.$ ) from the last 1000 years. Note significant increase since 1900 yr A.D. (IPCC, Cambridge, 2001). (e) Global temperature distribution (1860-1999) from measurements (black) and models (grey) (Stott P.A., et al., Science, 290, 2000, pp. 2133-2137). (f) Global sea level rise from satellite data (grey) between 1993 and 2005 (Cazenave, A. \& Nerem, R.S., Reviews of Geophysics, 42, 2004, p. 20).

- Sulfuric dioxide $\left(\mathrm{SO}_{2}\right)$ and nitric oxides $\left(\mathrm{NO}_{\mathrm{x}}\right)$ generated by volcanism and impact events [13] [14].

- Beryllium isotopes $\left(\delta^{10} \mathrm{Be}\right)$ in GISP 2 ice-core for verifying solar activity variation [6].

- Step by step disappearance/extinction of large Mammals and their robbery enemies [15] [16].

- Tektites (rock glass originated by impacting), [17] [18]. Tektites in wood for precise dendrochronlogic dating [19]. Fission tracking for age analysis [20].

- Another, rather major, however postulated, parameter, may relate to a large Comet that has possibly been crossing the Earth’s Orbit all 1600yr since Late Paleolithic about 12,300, 10,700, 9100, 7500, 5900, 4300, 2700, 1100 yr B. C., 500 yr A.D., and to be expected 2100 yr A.D. [21] [22].

In case of relative proximity to the Sun, the Comet would be warmed up and would thereby lose, in connec- 
tion with vaporization processes, solid extraterrestrial material by its repeated passage, to remain in the Earth's Orbit for possible impacts (follow Space Shuttle ROSETTA accompanying Comet CHURY).

By expecting a large size of the Comet, this also might have additional influence on the Earth's ecliptic and Magnetic Field variation or even for triggering magmatic processes on Earth [23], influencing in turn RCC.

- Major glaciation cycles (Milankovitch-Cycles: [24]) dominating the Pleistocene (1,800,000 -11,500 yr cal B.P.) are the result of Earth's Orbit and relating solar activity variation (Figure 3(b)). They control advance/retreat of continental ice masses accompanied by increase/decrease of $\mathrm{CO}_{2}$ and $\mathrm{CH}_{4}$ concentrations. Dominant periods of Earth's Orbit Cycles are 23,000, 41,000, 100,000, and 400,000 yr [11].

- Furthermore, during the last glaciation, about 20 abrupt dramatic RCCs (Dansgaard-Oeschger Events-DO) occurred, each within one to two decades revealing temperature rise of partially $12^{\circ} \mathrm{C}$, worldwide measured at 183 locations [11]. The last events (DO-1, DO-0) took place at the end of the last glaciation (Figure 3(a)). They obviously relate to an abrupt change of oceanic currents in the North Atlantic by a gigantic energy transport during a labile equilibrium between two different current patterns [11].

- Another climate evidence concerns the so-called "Heinrich-Events" yielding temperature cycles of several 1000 yr represented by sand and gravel layers intercalated with common fine-grained Atlantic deep sea oozes [11]. They result from melting processes during ice rafting in the North Atlantic which slows down oceanic currents followed by temperature fall in middle latitudes including the Mediterranean/Levant.

- Dating of Rise and Fall of Early Holocene Cultures is based on ${ }^{14} \mathrm{C}$ yr cal. B.P. analysis (B.P.:O = 1950 A.D.), see [25]. Dates of younger (historical) Holocene (B.C., A.D.) are taken from Koch [26].

- By applying the different genetic phases during an impact event, myths like mentioned above, are absolutely useful as data for comparison and realistic conclusions (comp. Chapter 5).

\section{Coincidence/Relation/Interchange of Natural and Cultural Patterns: 21 Cases Relevant throughout Holocene (Figure 4 (a), Figure 4(b))}

Already prior to the Pleistocene/Holocene boundary ( 11,500 yr cal. B. P.), there is evidence of two other Cases of relevant coincidence during the uppermost Paleolithic (Magdalenian) to be discussed:

Case 1:

DO-1, an acid-event, and $\mathrm{CH}_{4}$-peak ( 14,450 yr B.P.) which indicates an abrupt temperature rise, meet Hoyle's Comet (0). These processes possibly triggered the beginning of the NATUFIAN C. in Jordan and Israel [27], and the end of the highly developed MAGDALENIAN C. in southwestern France [28].

Case 2:

The beginning of the Younger Dryas ( 12,700 yr B.P.) coincides with Hoyle's Comet [1]; this falls into the initial phase of the ABU HUREYRA C., Syria [29] and seems to be related with an interruption of the NATUFIAN C.

\section{Case 3:}

The end of the Younger Dryas is marked by an abrupt temperature rise (DO-0) underlined by a $\mathrm{CH}_{4}$-peak, an acid-event, wetlands in moderate latitudes, droughts in low latitudes [30] [31], Plato's ATLANTIS Cataclysm Event [32], and the preliminary end of the ABU HUREYRA C, Syria. In Central Europe, the MESOLITHIC (FLANDRIAN Stage 11,500-7500 yr B.P.) poorly developed into the Preborial [33].

\section{Case 4:}

In turn, Hoyle's Comet (2), volcanic aerosols, and, after an interruption, the continuation of the ABU HUREYRA C. as well as the foundation of several "Towns" in Palestine (Jericho) and southern Jordan (Beidha, Basta, Basha) complete a remarkable Event-Ensemble [34].

\section{Case 5:}

The younger MESOLITHIC ( 10,000-9000 yr B.P.) exposes an overwhelming accumulation of hazards: this is Hoyle's Comet [3], a series of acid events [13], evidence of tektites [17] [18], euxinic sapropelites in the Eastern Mediterranean indicating oxygen deficit [35], stop of glacier retreat in alpine regions [6], tektites in wood for dendrochronologic dating [19], the impact-event of Köfels, Austria [36], the step by step disappearance/extinction of large heavy-weighted Mammals and their robbery enemies [15], and finally the last Mammoth found in Siberia [16]; a compilation of these events around 9600 yr B.P. see [37].

During the last third of the $10^{\text {th }}$ millennium B.P. “Towns” like Jericho, Beidha, Basta, and others in southern Jordan collapsed at all [38] while around the Northern Sea an unusually rapid sea level rise separated Britannia from the European Continent [33]. 


\section{Case 6:}

As precursor of the first large RCC 1 ( 9000-8000 yr B.P.), this Case relates to two acid events which are in coincidence with the end of the ABU HUREYRA C. [29], the Rise of both AIN GHAZAL, Jordan [39] and CATAL HÜYÜK, Turkey [40], later followed by CAYÖNÜ, Turkey [29], and the LEPENSKI VIR C., Serbia [41]. Both latter events also coincide with an aerosol event [13].

RCC 1 provided large ice sheets with a short-lived cooling in the North Atlantic (8 k-event: $~ 8200 y r$ B.P., [42]), strengthened atmospheric circulation, glacier advance in Scandinavia, glacier retreat in the European Alps, frequent polar outbreaks over the Aegean, summer monsoons over the Arabian Sea, and wide-spread aridity (droughts) in low latitudes [6].

The RCC 1 interval was accompanied by an unusually high aerosol production in the Northern Hemisphere possibly associated with impact events and decrease of $\mathrm{CO}_{2}$ and $\mathrm{CH}_{4}$ indicating lower temperatures.

\section{Case 7:}

There does exist another massive coincidence at the end of RCC 1 with Hoyle's Comet [4] and the cooling 8k-event in higher latitudes [42]. In connection with a drought interval in the Near/Middle East, Red Sea Region [6], the Cultures of CAYÖNÜ, CATAL HÜYÜK, and AIN GHAZAL found their end. It seems plausible that the drought-related collapse of these Cultures initiated a north-west-directed migration towards more convenient climate conditions to originate the Neolithic Cultures of KARANOVO (CHAVDAR), Bulgaria, in Slovakia, and Hungary, shortly later followed by rising Neolithic in Rumania [43].

Case 8:

A series of aerosol-events mainly caused by HEKLA-Volcanism, Iceland [13], reveal coincidence with the end of LEPENSKI VIR C. and the KARANOVA C. at CHAVDAR [43]. This is just the time when the export of actinolite-hornblende schist (AHS) as raw material for stone adzes/axes started from outcrops in the "dPZ"-

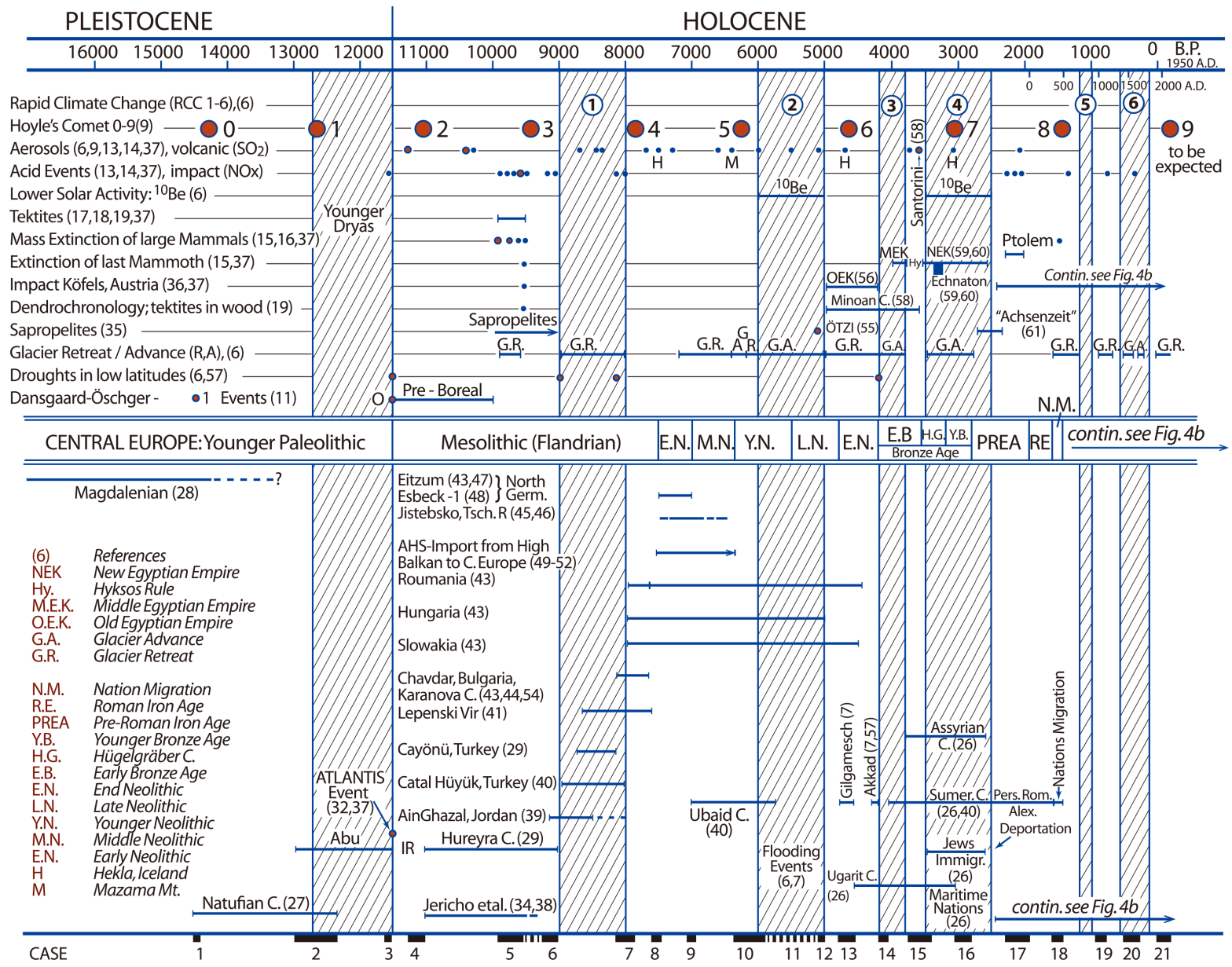

(a) 


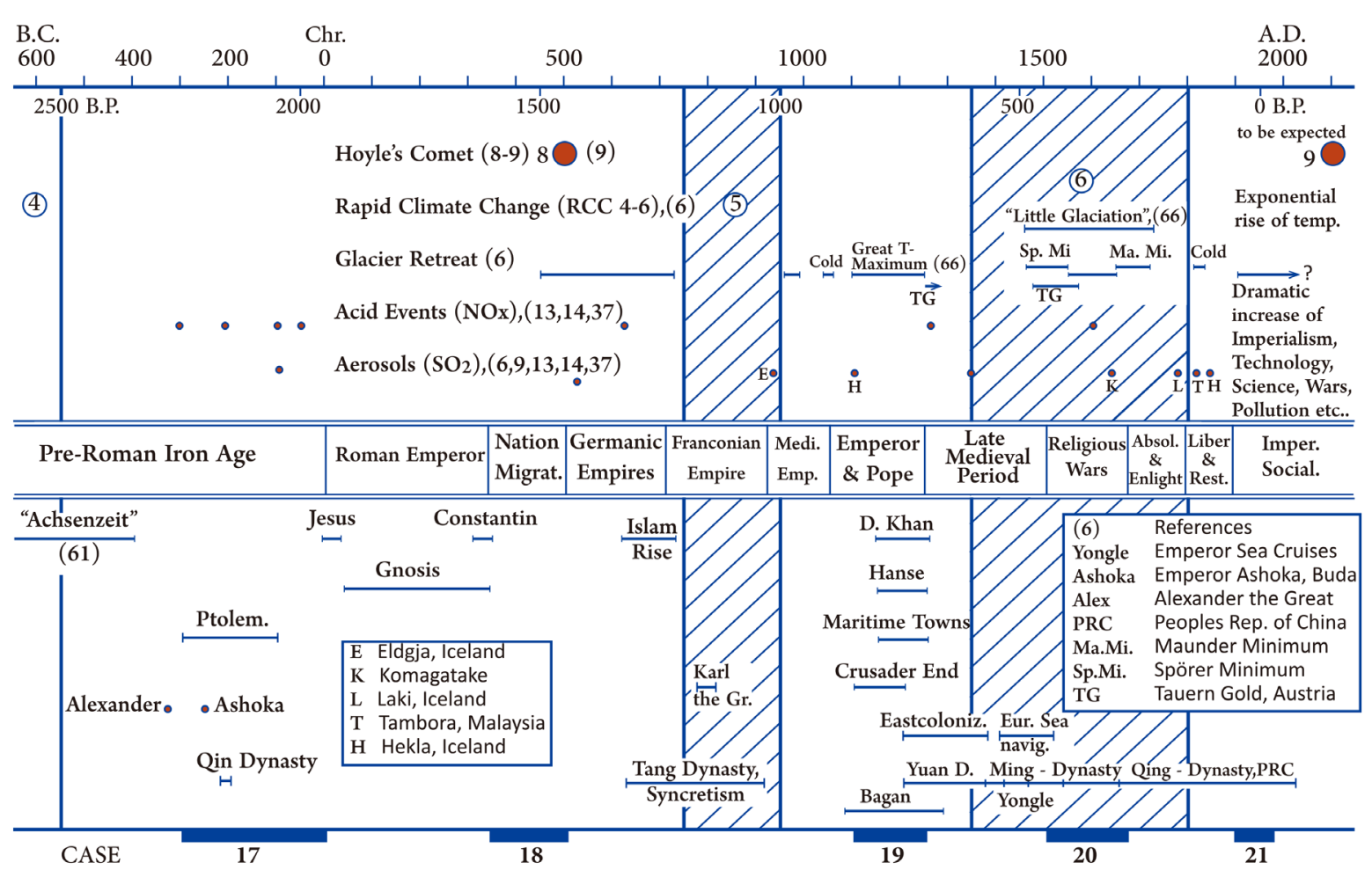

(b)

Figure 4. (a) Rise and Fall of human cultures in the Near/Middle East and in Central Europe throughout the last $15000 \mathrm{yr}$ opposed to natural events like RCC, mega-volcanism impact-events and others; (b) Like 4a, but more detailed for the last 2500 yr.

Formation of the High Balkans, Bulgaria [44] to Central Europe which worked contemporaneously with glacier retreat in the European Alpine Mountain Ranges [6].

Following immediately, may be within one century, the Early Neolithic LBK (Linien Bandkeramik) started at Jistebsko, Czech Republic [45] [46], at Eitzum [47], and at ESBECK [48], both the latter located in the Harz Mts. Foreland, North Germany. In other words: this AHS-import represents the earliest immigration of the "DANUBIAN CULTURE" to Central Europe [49]-[52] and herewith defines the MESOLITHIC/NEOLITHIC boundary in Central Europe.

Case 9:

During continuous glacier retreat in the Alps EARLY/MIDDLE NEOLITHIC boundary in Central Europe [53] coincides with the end of Eitzum LBK, North Germany and with the Rise of the UBAID C. IN Mesopotamia [40]. Recent studies at Herxheim excavation, West-Germany make sure that local BANDKERAMIK people practiced cannibalism with foreigners from remote mountainous areas up to some $450 \mathrm{~km}$ far from excavation site as varified by DNA analysis (ARTE Television: Cannibalen-Im Herzen Europas?, April 11. 2015). That would have happened through the last decadeof the EARL NEOLITHIC PERIOD, possibly the victims practiced a "Mensolithic lifestyle".

\section{Case 10/11:}

This time-span that started $\sim 6400 / 6300$ yr B.P. marks, apart from Cases 5/6, one of the most spectacular intervals throughout Holocene in Central Europe.

Hoyles Comet [5] and several volcanic outbreaks (i.e. Mt. Mazama, [13]) relate to the Middle/Younger Neolithic boundary while glacier advance [6] in the European Alpine ranges stopped the AHS export [49]-[52] from the ice-covered source areas in the Balkan Mts., what had been hitherto so successful. This led to an incisive decentralization of Cultures north respectively extinction, south of the Alpine Ranges [54].

This is also the time when the RCC 2 interval ( 6000-5000 yr B.P.) started a significant period that was characterized by North Atlantic ice-rafting, continuous Alpine Glacier Advance, and strengthened westerlies over the Atlantic [6]. 
In lower latitudes, it marked the end of the early/mid Holocene humid period in tropical Africa with the beginning of a long-termed trend of increasing rainfall variability across the Mediterranean/Levant and aridification (droughts) in Africa.

The UBAID C., Mesopotamia collapsed after the first third of RCC 2 that owns a decreasing solar output [6].

Case 12:

Contemporaneously with an acid event and the lifetime of "ÖTZI" the "ICE-MAN", Ötztaler Alpen, Austria ( $\sim 200$ yr B.P, [55]), the end of RCC 2 terminates the Neolithic in Hungary [43] after a long hazardous period in the Levant. During that time when the glaciers retreated in Europe, the OLD EGYPTIAN KINGDOM and the MINOAN C. started to rise [56].

Case 13:

Hoyle's Comet [6] and a Hekla outbreak [13] fall into the Kingdom of GILGAMESH ( 4750-4600 yr B.P., [7]). The end of the Kingdom coincides with the end of the Neolithic in Rumania and Slovakia [43]. At that time, the UGARIT C.. Syria [26] rose up at the eastern Mediterranean Coast as did the AKKADIC KINGDOM later ( 4340-4200 yr B. P., [57]). The Late/End Neolithic boundary coincides with the beginning of Case 13 period.

Case 14:

This interval is significantly related to RCC 3 ( 4200-3800 yr B.P) which appears less wide-spread. However, it provided a temperature fall throughout Eurasia, glacier retreat in Europe, and arid conditions in lower latitudes with distinct migration of the intertropical convergence zone [6].

The end of the AKKADIC C. under SARGON of AKKAD and the beginning of RCC 3 originated from an extreme and long-lasting drought in the Near/Middle East. It led to the collapse of this CULUTURE verified by an abrupt increase of $\delta^{18} \mathrm{O}$ isotopes in benthic foraminifera recovered from sediments of the Shaban-Deep/ Northern Red Sea (Figure 5, [57]).

The "GILGAMESH"-Epos as oldest written dating in "CUNEIFORM"-character, deals with the "DELUGE" on claystone Table 11 [7]. It stems from the AKKADIC PERIOD. However, according to Orientalists, the Epos was rewritten several times prior to Table 11 [7]. Thus, precursors of the Epos hint on that hazardous period before King GILGAMESH, but obviously shortly after the catastrophic flooding events between 6000-5000 yr B.P. The following extract tells part of evidence (7, transl. Koch, Schneider).

"The weather looked terrible... The ANNUNAKI (spirits of depths) raised up their torches to inflame the Country by their horrible brightness... Because of ADAD (God of weather) the sky fell into oppression, all brightness changing in darkness... The Country, the wide, broke like a pot... The southern storm blew for one day going to dip the mountains into water... Like a battle to subject human beings

....Nobody can see each other... By this 'DELUGE' the Deities frightened... The Deities remained weeping... Six days and seven nights continued the winds, the 'DELUGE'... The hurricane eroded the country... On the approaching seventh day the hurricane stopped the 'DELUGE' ... Looking around for one day there was silence... And mankind was completely transformed into soil”

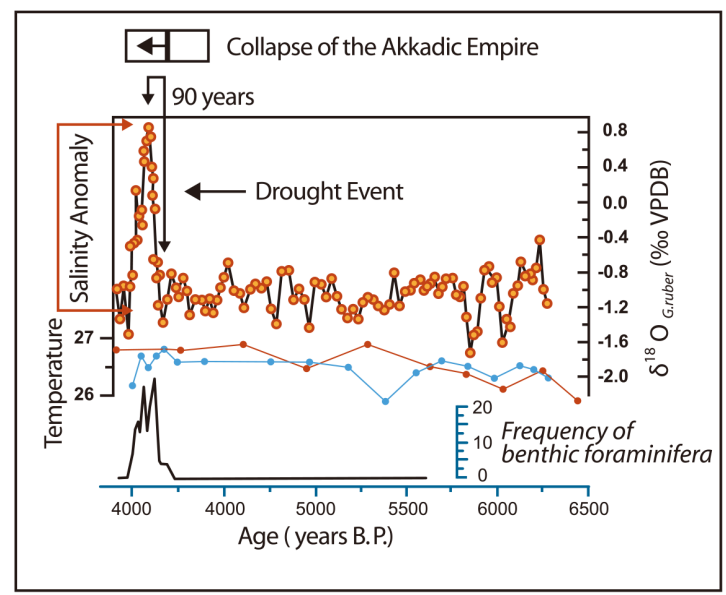

Figure 5. Drought-Event documented in sediments of the Shaban-Deep/Northern Red Sea, by $\delta^{18} \mathrm{O}$ isotopes in benthic foraminifera and salinity anomaly on $\sim 4200 \mathrm{yr}$ cal. B.P. It led to the collapse of the Akkadic Kingdom, Mesopotamia, from Arz et al. 2007 [57]. 
Thus, not only impact insiders may read evidence of typical impact features like wildfire [1], cataclysm [2], whirlstorm from south [3], erosion by tsunami [4], being close to the Sea [5], and complete destruction and extinction at all [6]. The setting described, was the Lowland of Mesopotamia that opens to the Persian Gulf and to possible tsunamis herewith. So possible impact sites of such hazardous events may have been located in southeastern direction (Persian Gulf, Indian Ocean, Saudi Arabia) on land/or in Sea.

The Old EGYPTION KINGDOM developed after the hazardous period RCC 2 and ended with the beginning of RCC 3, followed by the first INTERMEDIATE PERIOD that relates to a drought in low latitudes while in Central Europe the Early Bronze AGE rose up in connection with increased access to ore deposits in the European Alpine Regions favored by glacier retreat [6].

\section{Case 15:}

An aerosol-event and a gigantic eruption of the Mega-Volcano SANTORINI, Aegean Sea (3640 yr B.P., [58]) terminated the Middle EGYPTIAN KINGDOM and coincided with the HYKSOS-INVASION in the second INTERMEDIATE PERIOD in Egypt [56], as well as the JEWS (ARAMAEIC) IMMEGRATION to Palestine [26]. SANTORINI V. owns one of the highest energy indices of MEGA-VOLCANOES hitherto known.

This INTERVAL includes the NEW EGYPTIAN KINGDOM that presents a period of chaotic social conditions [59]. The SANTORINI eruption hit the rising NEW EGYPTIAN KINGDOM WITH tremendous masses of pumice ashes deposited across the whole Mediterranean/Levant and far more beyond [59].This event may explain all BIBLICAL PLAGUES in the Nile-Delta reported in the Old TESTAMENT [59] [60]. It also extinguished the MINOAN CULTURE, Crete by pumice ashes, wildfire, earthquakes and tsunami [58].

All this fits to the fact that PHARAOH ECHNATON [56] [59] [60] initiated religious revolutions by replacing the former Deities by the Sun (ATON) as the only GOD after a long interval of darkness and pollution by globally circulating volcanic ashes in the atmosphere/stratosphere (cosmic winter, sint winter).

Modern excavations exhibit amazing evidence on ECHNATON'S Capital AMARNA [60]. During this chaotic time, AMARNA seemed a place of wealth and food abundance (800 sacrifice tables in the ANTON Temple).

However, it surprisingly reveals suffering of population: there are definite indications on severe diseases (anaemia, parasites, infections, genetic defects concerning spinal cord) accompanied by a high death rate of children and young people (15 - $20 \mathrm{yr})$. ECHNATON'S wife NOFRETETE disappeared in her $12^{\text {th }}$ year of reign, her daughter followed two years later and ECHNATON died in his $17^{\text {th }}$ year of reign, his corpse was never found [60].

After ECHNATON'S death the former deities were re-introduced.

Thus, it seems realistic to relate the chaotic AMARNA-Interval as also being confirmed for the Nile-Delta, to effects of aerosols, environmental pollution, ashes and acids of SANTORINI products.

The period of the NEW EGYPTIAN KINGDOM and that of the HÜGELGRÄBER C. in Central EUROPE cover the first third of RCC4.

RCC4 (3500-2500 yr B.P) exhibits the same basic pattern like RCC2 concerning glacier advance in Europe, cooling over the northeast Mediterranean is related to winter time continental polar outbreaks and pronounced aridity in East Africa. $\delta^{10}$ Be-MAXIMA indicate lower solar activity, may be in connection with SANTORINI V.

During the Dynasty of ECHNATON the UGARIT C. collapsed in connection with the ingression of the MARITIME NATIONS that moved along the eastern Mediterranean Coast [26] while the ASSYRIAN KINGDOM continuously developed since the end of RCC 3.

The UGARIT C. had used character-writing as a precursor of the ancient Hebraic writing [7]. So the Jews were in the position to receive information on catastrophes that had happened in the Near/Middle East, from both SUMERIAN C, and UGARIT C, that would be an early realistic source for "JOHN'S APOCALYPSE" [8].

The JEWS'DEPORTATION by the Assyrians took place in 587 yr B.C. and might had been a delayed chance to be refaced with the subject of "DELUGE" [7].

\section{Case 16:}

Hoyle's Comet [7] and a further Hekla outbreak dominated the RCC4 interval in relation to decreased solar activity and a change of glacier advance to glacier retreat. The latter coincides with the Younger Bronze Age/ Pre-Roman Iron Age b. (boundary) and with the end of the MARITIME NATIONS' MIGARATION as with the Middle/Younger ASSYRIAN KINGDOM b.

At the end of RCC 4 the EGYPTIAN KINGDOM and ASSYRIAN KINGDOM ran out while the SUMERIAN C. was replaced by the PERSIAN EMPIRE [26].

During the $6^{\text {th }}$ and $5^{\text {th }}$ century B.C. a significant spiritual development happened which gave rise for: a. the 
Philosophical Systems in Greece (Heraklit, Thales, Pythagoras followed by Plato and Socrates), b. the Systems in China (Lao-tse, Kungfuzius et al.), c. Buddhism in India (Buddha), d. the Hinduistic Religion in India (Bhagavadgita, Upanischads), and e. Zoroaster (Zarathustra) in Persia. This exorbitant concentration of spiritual activities through moderate latitudes would be possibly unique in Human History. Jaspers [61] termed it therefore "Die ACHSENZEIT" of Human History.

Case 17:

(from here on see Figure 4(b))

Three acid events and a volcanic outbreak occurred during the interval $2300-2000$ yr B.P. There is the rise of the SELECEUDS, the PTOLEMEANS' rise and fall, and ALEXANDER the GREAT. Its end defines the beginning of the ROMAN EMPIRE and the PRE-ROMAN/ROMAN IRON AGE b. The interval also houses Emporer ASHOKA’S Buddhistic Missions between Far and Middle East, and Qin Dynasty in China.

Case 18:

Hoyle's Comet [8] and a volcanic event, combined with glacier retreat in the European Alpine Regions, exhibit through an interval of significant temperature increase coincidence with the NATIONS' MIGRATION and with the establishment of GERMANIC (TEUTONIC) NATIONS [62].

The end of this time-span relates to the rising ISLAMIC RELIGION [63] and to the peaceful TANG DYNASTY in China characterized by SYNCRETISM [64].

The following short-lived RCC 5 ( 1200-1000 yr B.P.) seems less important, but nevertheless of global-scale teleconnection: winds over the North Atlantic and Sibiria were weak, temperature fall in Eurasia, increase of Atlantic deep water production, and changes of solar output [6].

This short interval owns the drought-related collapse of the MAYA C. [57] [65] and shows a volcanic event at its end [9] [13], coinciding with the end of TANG Dynasty. The FRANCONIAN IMPERIUM covers almost completely RCC 5.

Case 19:

This interval is significantly dominated by a temperature maximum ( 1100-1255 yr A.D.) in Central Europe (Figure 6, [66]).

There appears a massive coincidence of the EMPEROR/PONTIFICATE INTERCHANGE in Europe with a great number of outstanding historical occurrences in the Northern Hemisphere, like: a. the activities of the HANSE, b. such of the MARITIME CAPITALS (Venice, Genus, Pisa), c. the CRUSADER'S ENDEAVORS, d. beginning of the EAST-COLONIZATION, and e. the extraordinary extension of the MONGOLIAN EMPIRE (YUAN DYNASTY) under DSCHINGIS KHAN [67]. The THERAVADA BUDDHISTIC PAGODA FIELD AT PAGAN, MYANMAR was built up to 1084-1287 A.D.

At the end of this thermal maximum (glacier retreat) and, contemporaneously with an aerosol-event, the gold/ quartz dikes in the Hohe Tauern, Austria were discovered [68].

Case 20:

The RCC 6 ( 1350-1800 yr AD.) followed with features like: cool poles, wet tropics, glacier advance in the Northern Hemisphere, strengthened westerlies over the North Atlantic and Sibiria [6].

Climate changes yield the fastest and strongest onset of any in the Holocene except of the 8k-Event [6]. Furthermore high level of aerosols; sun spot records indicate strong solar variation that had severe influence on climate through 1460-1720 yr A.D (Figure 6).

The most important event relating to historical evidence concerns the so-called "LITTLE GLACIATION" [66]. This interval owns two minima (Spörer Min.:1460-1550, Mounder Mi.: 1650-1720 yr A.D.). Intercalated is a maximum (1550-1650 yr A.D.) comprising an acid event on 1600 yr A.D., later followed by a subordinate temperature maximum (Figure 6). The RELIGION WARS [69] took place during the temperature maximum.

The LAKI-ERUPTION, Iceland (1783) produced large volumes of $\mathrm{SO}_{2}$ and $\mathrm{HF}$ with catastrophic influence on agriculture, death rate of animals and people as well as politics in Europe (French revolution) (TV ARTE, 2014, [8] [16]).

Case 21 with open end

Temperature on the Earth began to significantly increase under additional influence of mankind (Figure 3(c)). characterized by Industrialization, Imperialism, Capitalism, Socialism, and a dramatic development of Science and Technology, the consequences culminated in a more or less continuous sequence of regional and global wars [70]. 


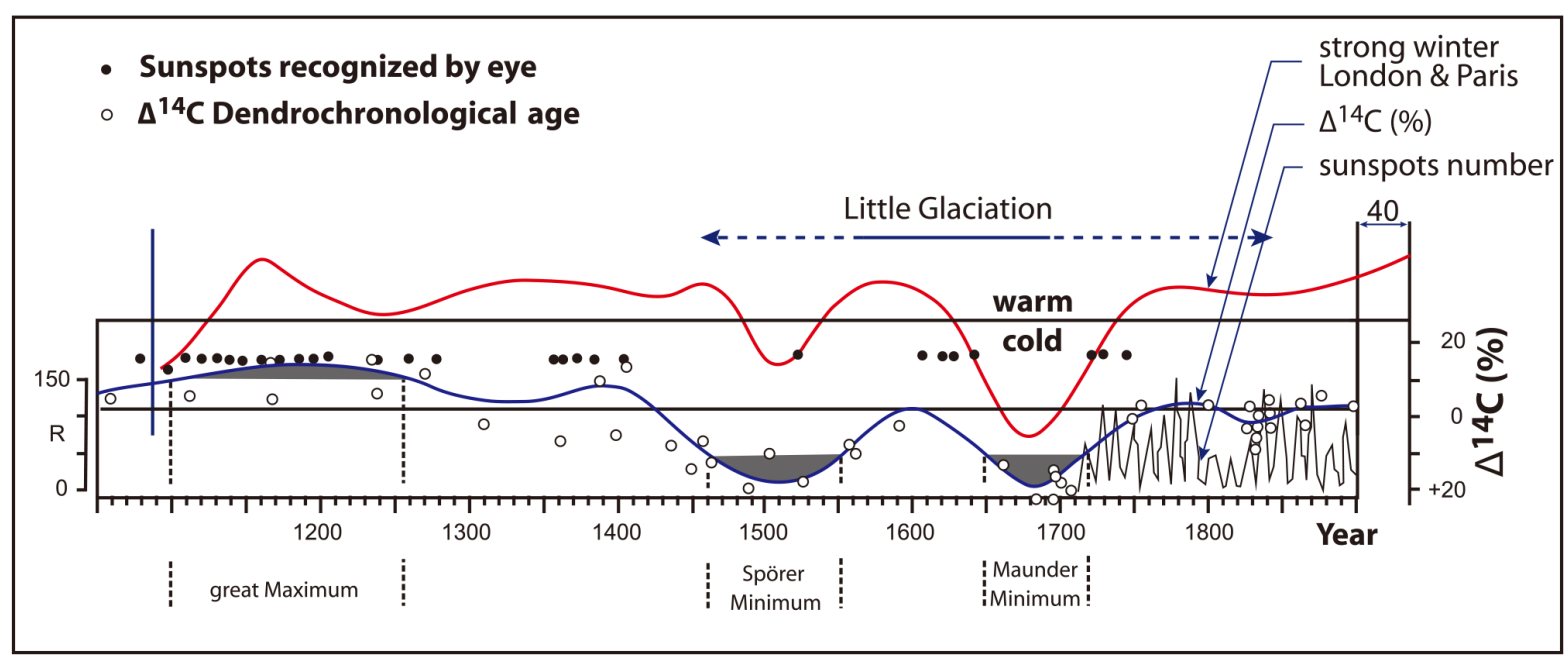

Figure 6. Climate variation (London, Paris) throughout 1100-1900 A.D. showing two striking intervals: The "Great Maximum" $1100-1250$ A.D.) and the "Little Glaciation” (1450-1800 A.D.) verified from ${ }^{14} \mathrm{C}$-dendrochronologic dating and number of eye-observed sunspots, from Negendank 1995 [66].

National power strategies and unreflected aggressive exploitation of natural resources have created a world of one-sided materialistic over-production, increasing environmental pollution, decreasing number of Species as well as overregional refugee streams and climatic hazards under further continuous temperature rise (see REPORTS TO AND OF THE CLUB OF ROME: the last one [71]).

Uncontrolled use of IT provides the way to hyper-capitalism increasing, global confusion and increasing collapse events. It is realistic that "Homo Sapiens Species" would be the first species in Earth History to destroy and pollute wide realms of Earth's surface on global scale.

Under such dusky aspects we are looking forward with mixed feeling to possibly meet Hoyle's Comet (9) to be expected about $\sim 2100$ yr A.D.

\section{Why Can Myths Like "John's Apocalypse” Be Useful for Modern Greoscience? -Evidence of Impact Processes and Other "Rare Events" in Myths of the Near/Middle East}

"Der intuitive Geist ist ein heiliges Geschenk und der rationale Verstand sein treuer Diener. Wir haben eine Gesellschaft geschaffen, die den Diener verehrt und das Geschenk vergessen hat”.

Albert Einstein

Compilations of three Austrian authors [37] [72] provide an overwhelming abundance of Myths of indigenous peoples from around the Globe that deal with the subject "DELUGE". There do exist so many relevant mythological information from all continents concerning this subject that it seems more than enough to restrict our focus only onto the NEAR/MIDDLE EAST. Thus, the most informative source is the "REVELATION OF JOHN" (APOCALYPSE) to be read in the NEW Testament of the Bible or in a rather modern translation by W. Jens [8], especially CHAPT. 6 - 16 as well as in the GENESIS of the OLD TESTAMENT (1./2.Book MOSE).

Inspite of the mythologic language, the text of the Myths surprisingly appears realistic: starting with the observation of approaching extraterrestrial bodies, mentioning the impact, the following earthquakes and faulting, supercyclonic whirlstorms (wildfires), the effect of hot/melted ejecta over long distances, destruction of fauna and flora (including human beings), and Towns!, and finally long-lasting flooding, darkness (sintwinter) as well as environmental pollution, as follows (transl. Koch, Schneider):

\section{Observation of approaching bolides:}

... "and the stars in the sky fell to Earth, as late figs drop from a fig-tree when shaken by a strong wind" (Apc. 6, 13),

"Then I saw another mighty angle coming down from Heaven,... His face was like a sun, and his legs were 
like fiery pillars” (Apc. 10, 1).

"A giant star, blazing like a torch, fell down from Heaven, on one third of the rivers, and on the springs of water” (Apc. 8, 10).

“A gigantic mountain looking like a huge rock boulder, that burst in fire storms”,... (Apc. 8, 8).

For further reading, the "Revelation of John" generally points to seven major "trumpets" (extraterrestrial bodies), in each case accompanied by a "fire-work" of smaller fragments.

\section{The Impact:}

"But then, the angel took the pan, filled it with glowing fire from the altar, threw it to the ground. What a noise and quaking” (Apc. 8, 5).

"... As this star received a key that opened the door to the springs of the abyss. Smoke ascended from the spring, so as coming through the chimney of a gigantic furnace, and darkening the Sun and the Sky..." (Apc. 9, 1-2).

“... there was a massive darkness by dust and soot through whole Egypt for three days” (2. Mose, 10, 22).

\section{Shock Wave, Brecciation, Earthquakes and Faulting:}

“... and that happened at the hour when the Earth commenced to quake. One tenth of all houses broke down, 7000 people were killed”... (Apc. 11, 13).

“... thundernoise and a tremendous earthquake occurred, as has never been since human beings live on Earth”... (Apc. 16,18).

"The Islands changed their position, coastlines disappeared, mountains were never found" (Apc. 16, 20).

\section{Super-cyclonic Whirlstorms and Heatstorms (Wildfires):}

"A third of the Earth was burnt out, a third of the trees was burnt out, and all the green grass was burnt out..." (Apc. 8, 7).

“...to let human beings burn. They dried out in the heat...” (Apc. 16, 8).

\section{Ejecta:}

“... and out of the soot fell grasshoppers, giant vermins down to the Eath...” (Apc.9, 3)... "The bodies of the grasshoppers looked like the bellies of wild horses that rush into a battle” (Apc. 9, 7).

“... and a gigantic hail including boulder of hundred weight came down from Heaven over human beings..." (Apc. 16, 21).

“....Red and black dust like the soot from the furnace was raised over the whole land of Egypt”... "and the worst hailstorm that has ever fallen on Egypt"... "The stones that fell upon Egypt were hot"... "Hail and fire were intermingled"... "The hail was accompanied by a rolling thunder, and it smashed everything that was in the open country, every man and animal, and everything growing in the field, and it stripped every tree" (2. Mose 9, 23-25).

\section{Explosive Ascent of Groundwater:}

“... break up all springs of the deep abyss...” (1. Mose 7, 11).

“... at this hour the Lord opened the springs of the abyss [73].

\section{Acid Rain and Environmental Pollution/Flooding:}

“... Jehove let rain down burning sulfur on Sodom and Gomorra out of the Heaven. Thus, he overthrew these Cities and the entire plain, and also the vegetation in the land, and he saw dense smoke rising from the land like from a furnace (1. Mose 19, 24-25).

“... and a rain came on Earth 40 days and 40 nights” (1. Mose 7, 12).

“... and the water remained 150 days on the Earth” (1. Mose 7, 24),

"... there got drowned all flesh, all animals creeping on Earth, the birds, the cattle and all what has moved on the Earth, and all human beings" (1. Mose 7, 21).

“... and the water became abundant and rose up so much on Earth that all high mountains were covered beneath the whole sky" $(1$. Mose 7,19$)$. 
“and the water regressed step by step after 150 days" (1. Mose 8, 3).

“... and all the water in the stream changed into blood" (2. Mose 7, 20),... and the fishes in the stream died and the stream owned a strong smell, so that the Egyptians could not drink water from the stream, and there was blood in whole Egyptian Land" (2. Mose 7, 21). The "blood" means nitric acid $\left(\mathrm{HNO}_{3}\right)$ !

“...Look, I will plague your whole area with frogs” (2. Mose 7, 27).

Even the much younger KORAN mentions the "DELUGE”: “...and oh, Heaven, keep back your rain” (KORAN 11, 45)., probably a younger event!

When comparing the high number ( 180) of "DELUGE" references all of them reveal similar significant contents of hazardous events, i.e. Figure 7.

\section{Discussion: Critical Aspects to the Parameters Applied}

“The 'Rare Event' in Geology is defined as a spasm, episode or punctuation of such of a low rate of occurrence that it has taken place at most a few times through all of Earth History. There is no known physical law that permits to relegate such highly improbable events into the realm of the impossible" [74].

\section{P.E. Gretener}

Some of the following parameters to be discussed, mainly the first of them, run under this aspect.

\section{Hoyle's Comet:}

This Comet concept was primarily submitted by Clube and Napier [21] [22] who stressed the rare, but possible process that a large comet crossed the Earth's orbit some 15000 yr ago thereby having lost solid material.

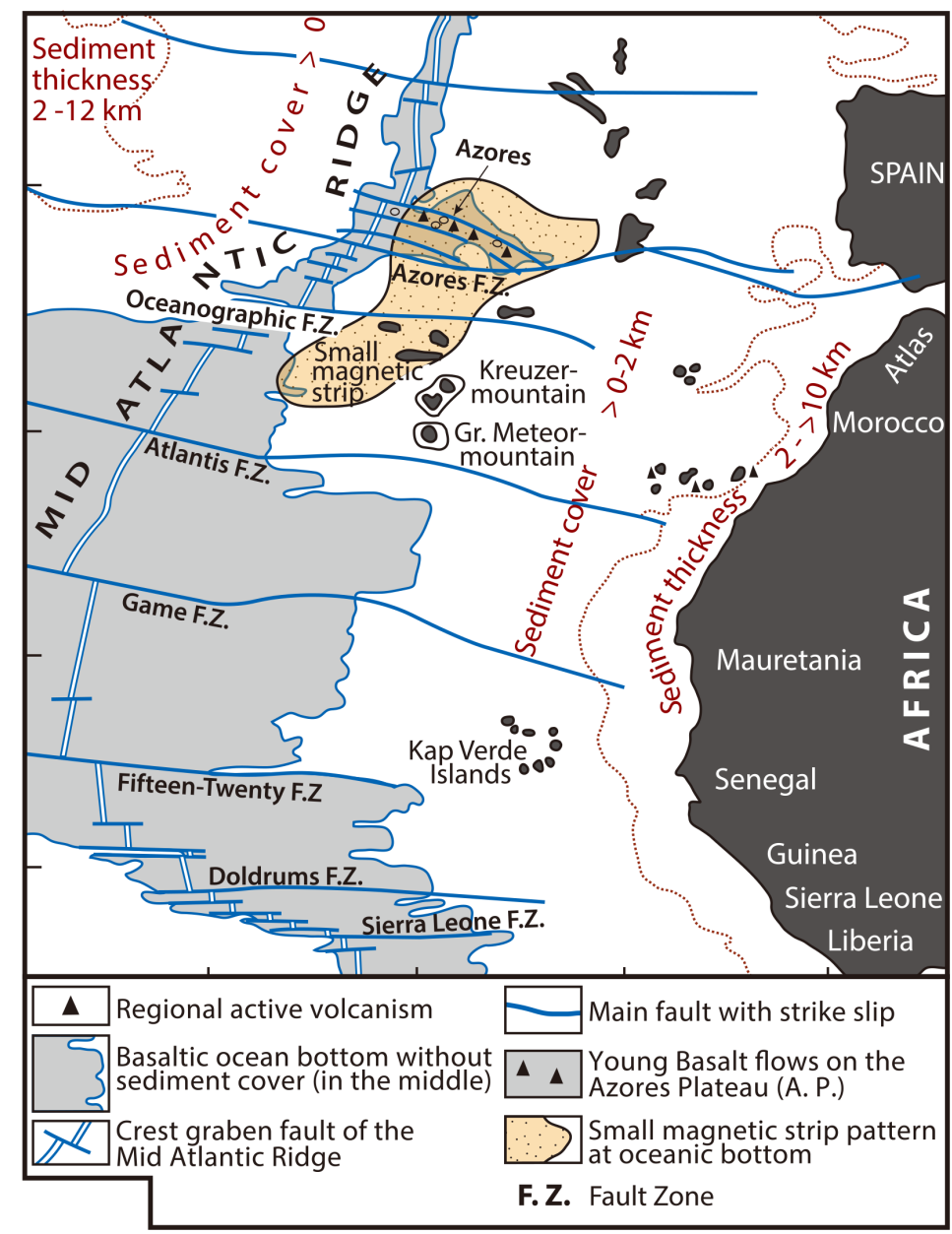

(a) 


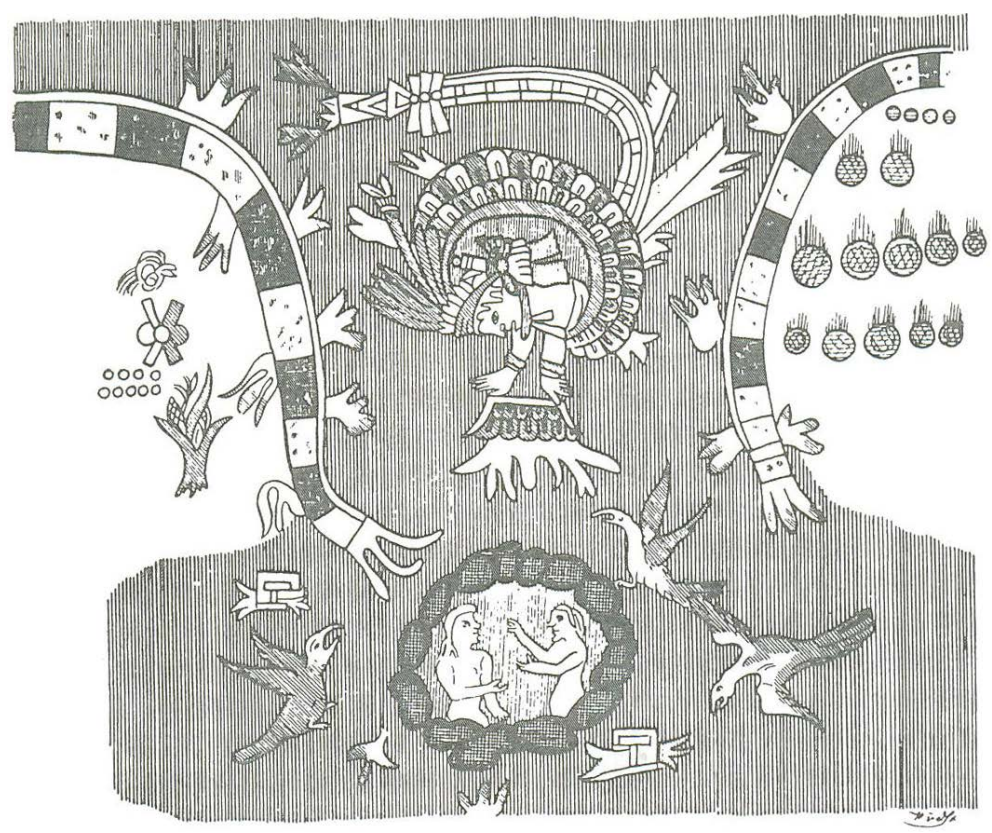

(b)

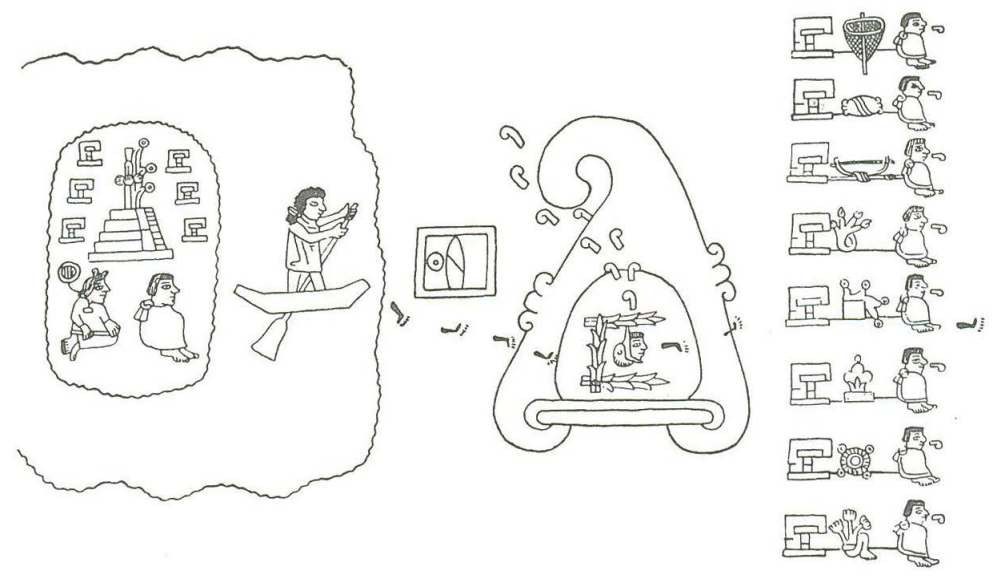

(c)

Figure 7. Atlantis-Event, based on Plato [32], analyzed by A. \& E. Tollmann 1993 [37]. (a) Possible geologic position of ATLANTIS Island (Axtland on the Azores Plateau controlled by the Mid-Atlantic Ridge and the Azores Transform Fault striking west-east towards Gibraltar. Missing magnetic pattern indicates strong tectonic destruction across this Triple Junction, and irregular basaltic volcanism under high $\mathrm{H}_{2} \mathrm{O}$ availability. Based on Emery, K.O. \& Uchupi, E.: The gGeology of the Atlantic Ocean (XIX, 1050 p.), Ney York, Springer, 1984. (b) The inhabitants (Azteks) of Aztlan (Atlantis?) leave their Island (homeland) by boat on the way to Mexico to the Holy Mt. Teocolhuacan characterized by a curved top region. There they found a cave shelter (Chicomoztoc) from where the later eight Aztec Tribes developed (Codex Boturini. Kingsborough, Mexican Antiquities, Vol. 1 [37]). (c) Obviously, the cause of escape was a tremendous impact-event or another hazard or both across the Azores at that time (see a massive bombardment by meteorites and cataclysm at all) (Codex Vaticanus Nr. 3738, Fol. 6, verso. Ms. Mexicains de la Bibliothe'que, 51-53 [37]).

The circumstances for such an event lie in necessity of gravitationally initiated Comet deviation from its own orbit by meeting both a molecule cloud/material accumulation in the Universe and consequently passing closely a planet of our Solar System in order to meet a position of being so close to the Sun as does the Earth. This has to be the condition for losing solid fragments after warming up, to remain in the Earth's orbit as potential bolides for impacting the Earth.

The authors postulate a time-span of several decades to one century for all fragments per passage through the Inner Solar System all 1600 yr periodically. That means no definite impact date, rather a temporal variation 
during one passage. By assuming i.e. a bolide diameter of 100 meters, see Tunguska type [9], some 1000 lucky strikes onto Earth would be reasonable per Comet passage.

Clube and Napier focus Rise and Fall of Cultures on a bundle of such "Tunguska-Events". They relate the collapse of Cultures to short intervals owning strong hazardous events when Religions and Cultures undergo stress situations with dark psychic character while balanced rise and constructive growth originate tolerant Religions and peaceful pathways (see Syncretism in TANG Dynasty, China).

However, as modern climate records through Holocene reveal [6], there is needed to discriminate RCCs in latitude scale according to the geographical distribution of Cultures. Consequently, we follow Majewski et al. to use the climate data of the Northern Hemisphere for subdivision in high latitude zones (ice-rafting, glacier advance), Middle latitude zones (cool humid, flooding, partly glacier advance in European Alpine Regions), and low latitudes (arid conditions, droughts).

Acceptance of Hoyle's Comet depends on reliable facts: If coincidence of the Comet with RCCs would be low, it would have had no relevance as parameter for this paper. But there appears a massive coincidence with climate variation, tektite fall, acid events, partial extinction of Mammals, and the respective influence on Cultures. So it should be seriously accepted in spite of temporal variation of possible bolide impacts during 100 years per Comet passage.

\section{Rapid Climate Change (RCC):}

Majewski et al.'s compilation and interpretation of Holocene climate variation represents a substantial approximation for serving as a framework for additional data available in the future. Highly resolved sampling and use of published proxy data of geographic record distribution are a useful base for latitude zone discrimination like high l. (North/Central Europe), middle l. (Southern Europe, Mediterranean/Levant, North Africa), and low 1 (Tropical Africa).

For recognition of climate-controlled time-spans. it deals as an excellent data base for this paper by application of cosmogenetic isotopes verifying solar activity variation $\left({ }^{10} \mathrm{Be}\right)$, orbital solar variation, temperature variation $\left({ }^{18} 0\right)$, glacier fluctuation, Green House gases $\left(\mathrm{CO}_{2}, \mathrm{CH}_{4}, \mathrm{NO}_{\mathrm{X}}\right.$, etc.) to be applied to the definite latitude zones.

The RCC-dating involves uncertainties of less $500 \mathrm{yr}$, similar to calibrated radiocarbon ages of the Cultures presented [12].

\section{Aerosols and Acid Events:}

Both can reliably be analyzed from ice-cores by $\sim 170$ yr analytical uncertainty [13]. But it should be stressed that aerosols presented in reference lists generally relate to volcanic processes. Though sulfuric oxide $\left(\mathrm{SO}_{2}\right)$ is a main gas component therein, other magmatic gases like hydrochloric (HCL), hydrofluoric (HF) and carbon dioxide $\left(\mathrm{CO}_{2}\right)$ generate, in connection with water, aggressive acids.

By discriminating acid events from aerosols, one has to focus on nitric oxide $\left(\mathrm{NO}_{\mathrm{x}}\right)$ generated by impact processes from nitrogen air molecules under high energy, and by modern human technology as well, to originate the most aggressive nitric acid $\left(\mathrm{HNO}_{3}\right)$. Meanwhile both can analytically be distinguished [14].

Extremely high acidity ( $\mathrm{pH}=0-1)$ is to be expected in impact centers [26]. That results in massive dissolution processes concerning both calcareous and silicate rocks and cause, as well, strong etching of inorganic and organic matter. Such acid solutions dissolve metals like $\mathrm{Pb}, \mathrm{Hg}, \mathrm{Cd}, \mathrm{Ti}, \mathrm{Cu}, \mathrm{Ni}, \mathrm{Mn}, \mathrm{Zn}$ and many others as trace elements from water insoluble components causing pollution, genetic defects, and locally death of flora and fauna [26].

However, in Figure 4(a), Figure 4(b) we separate known volcanic activities generating $\mathrm{SO}_{2}$, being conscious that, both $\mathrm{SO}_{2}$ and $\mathrm{CO}_{2}$ may also be contributed by impact events which depend on the rock chemistry of the target area.

In cases without any indication of contemporary volcanism, acid events preserved in ice-cores are interpreted as of impact origin.

\section{Tektites/Microtektites:}

As condensation/ melting products of impacting meteorites onto $\mathrm{SiO}_{2}$-rich surface sediments/ rocks exposed in the target area, tektites provide reliable impact event criteria [17] [18]. Their strewn fields may be localized far remote from the impact site, and not every impact originates tektites depending on the surface rock chemistry. Age analysis relates to fission tracking and ${ }^{40} \mathrm{~K}$ method [20].

Most relevant is the Austral-Asian strewn field (Australia, Indic Ocean, South China, Thailand, Lao, Cambodia) covering 50 Mio square kilometers, owning some 100 Mio tons only of microtektites [17] [18] and ranging 
in age in between $~ 10000-9545 \pm 200$ yr B.P. The latter age coincides with the age of tektites in wood analyzed by ${ }^{14} \mathrm{C}$ and/dendrochronological method [19].

The data very probably represent one of the strongest and most hazardous impact events throughout Holocene (see Figure 4(a)). Seven to nine major impacts to have hit the Earth more or less simultaneously on Land and Sea, are discussed (i.e. [37] [72]).

Large Mammals and their robbery enemies:

Former publications report an extinction wave of half of all large Mammals species' of more than five kilogram body weight shortly after the end of Pleistocene. There was a total extinction of this animal group in America and Europe with a body weight of more than 1000 kilogram (3/4 of species) that died abruptly [15]. All in all: mainly concerned were the plant eating animals and their robbery enemies (controversaries see [37]).

European Mammoth finds date on $\sim 10000-9000$ yr B. P., a young Mammoth found in Siberia reveals $~ 9600$ yr B.P. \pm 300 yr (web) and $\sim 9730$ yr B. P. \pm 100 yr [16].

One reason for mass extinction lies in the decrease/stop of photosynthesis of plants as common food for Mammals, caused by ashes, dust, soot that circulated in the atmosphere/stratosphere over months in the Northern Hemisphere, even years around the globe which darkened the Sun (Figure 8, [75]). This scenario was accompanied by wildfires, chaotic conditions, pollution, flooding, and sintwinter; a synopsis see [37] [73].

Role of Myths in Modern Geosciences:

The biblical quotations cited above, appear surprisingly realistic despite of their mythological origin. They represent prehistoric sources orally surrendered down to the first Sumerian writing in "Cuneiform character" published in the GILGAMESH-Epos. The observers of the "APOCALYPSE" do obviously not have a vision relating to future they describe realistic processes on Earth during impact "Rare Events" in the language of their time and ethnologic position.

According to the frequency of impacts on Earth [23], there cannot be any doubt that almost all "DELUGE" REPORTS OF SOME 180 ETHNIC PEOPLES (37.73) are based on a remarkable high, but unknown number and age of "RARE EVENTS".

Hence, Myths provide a serious tool to study subjects in transitional fields of Science.

It is amazing how human mind diverges in the interpretation of "JOHN'S REVELATION".

So did the German Theologian and Psychotherapist E. Drewermann [76] stress the necessity of psychologic interpretation. He brought all the processes cited in Chapter 4, in connection with human psychic suffering, guilt, and anxiety relating to own moral weakness, and "Fall of Man" as well as with the Roman occupation of the "HOLY LAND”. A similar way of psychologic-philosophical interpretation was given by Ellul [77].

The Myth of ATLANTIS

Studies of the Tollmanns [37] make evident that, according to Plato (427-347 yr B.C., [32]) via Solon (6 ${ }^{\text {th }}$ century B.C.) who got his knowledge from Egyptian priests of Sais, ATLANTIS did exist and collapsed by

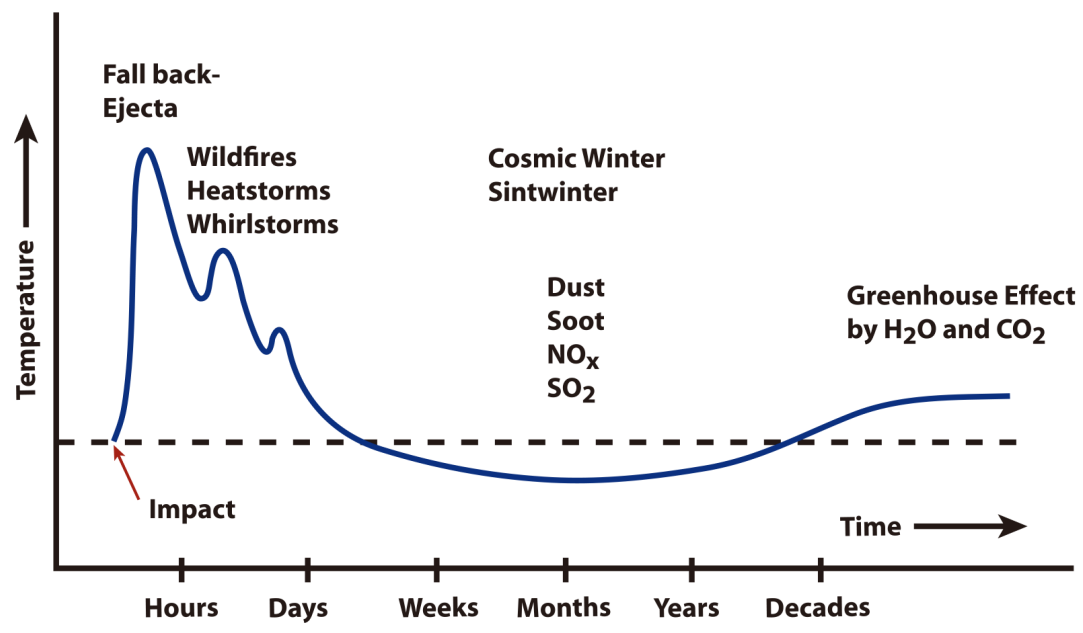

Figure 8. Temporal distribution of a. ejecta (wildfires), b. effect of dust, soot and gases (sintwinter) and c. the following Green House atmosphere after a major impact, from Stöffler 2002 (750). 
earthquakes and flooding $\sim 9000 \mathrm{yr}$ before his time ( 11,500 yr B.P.). This is just the time when the last glaciations ended (Younger Dryas) followed by sea level rise.

The relevant area is to be assumed on the AZORES PLATFORM located in the western prolongation of the Mediterranean Sea (AZORES FAULT ZONE) as an eastern part of the MID-ATLANTIC RIDGE (Eastern Rift Zone).

The area is characterized by missing magnetic stripe patterns obviously destroyed by geologic processes (Figure 7(a)). However, this zone exhibits a thin labile oceanic crust in a highly active volcanic region.

Therefore, since the time of ATLANTIS' collapse and sea level rise after the younger Dryas glaciation coincide (if Plato's issue is true), this would be a simple explanation of the ATLANTIS problem.

Certainly, volcanism in context with plate tectonics could have played an additional role just without any impact.

Figure 7(b) shows the Island of AZTLAN (localized in the Atlantic ) when the AZTEK antecessors left their "Home-Island" on the way to Mexico (Mt. Teocolemacan ), their Holy Mountain, that in reality owns a curved top where they found a shelter in caves having escaped from cataclysm of ATLANTIS ISLAND (Figure 7(c)).

\section{Conclusions}

\subsection{General Aspects Relating to Natural Processes}

Generally speaking, there does exist an overwhelming complex coincidence, relation, and dependence of Rise and Fall of Cultures with very frequent natural phenomena in the Northern Hemisphere throughout the last $15,000 \mathrm{yr}$.

Obviously, the complete event-scenario exhibits a hierarchy of the parameters used, as follows:

- Hoyle's Comet ( 0 - 8) and other extraterrestrial bolides cause impacts on land and sea (initiating Tsunamis) $\rightarrow$ triggering earthquakes and possibly volcanism, wildfires of overregional extension $\rightarrow$ ejecta like rock boulders, ashes, dust, soot, and gases generating environmental pollution and decreasing solar energy (sint winter, cosmic winter), and temperature $\rightarrow$ preventing photosynthesis followed by partial/complete mass extinction of flora and fauna (including Human Cultures). Major impacts may trigger plate tectonic processes while Green House Gases initiate temperature increase.

- Mega-Volcanism (i.e. Santorini, Greece; Hekla, Iceland) generates earthquakes, tsunamis, ejecta (ashes, dust, gases like $\mathrm{SO}_{2}, \mathrm{CO}_{2}, \mathrm{HCl}, \mathrm{HF}$ ) causing environmental pollution and temperature decrease (sintwinter), collapse of Human Cultures $\rightarrow$ refugee migration, wars $\rightarrow$ later Green House effect generating temperature increase, drought with similar consequences. In cases of major impacts onto carbonate target rocks (see JWS) tremendous volumes of $\mathrm{CO}_{2}$ reinforce the Green House effect.

- Apart from temperature change of cosmic origin (solar activity, Earth orbit), DO-Events (abrupt change of oceanic currents), Heinrich-EVENTS (melting processes in the North Atlantic), and Green House Effects $\left(\mathrm{CO}_{2}, \mathrm{CH}_{4}, \mathrm{NO}_{\mathrm{X}}\right.$, and others) contribute to significant temperature increase. This implies a higher availability of thermal energy for flora and fauna to be used for progressive activities.

There results an increased ice-melting in higher latitudes, glacier retreat in alpine regions initiating higher mobility concerning migration of peoples and exploration of ore deposits, and water deficit, droughts, and wars in lower latitudes.

Since the end of the last glaciation, temperature-related sea level rise amounts up to some 120 meters mainly concerning coastal areas of huge extension and former submerged land corridors which has had an global influence of shelf-situated Cultures and animal migration.

In many cases temperature decrease meets mega-volcanic and impact events with regard to ejecta into the atmosphere and stratosphere to generate sintwinter, glacier advance including restricted mobility and access to specific rock and ore deposits (AHS) followed by chaotic migration and collapse of Cultures.

The current temperature increase since 1880 yr A.D. is definitely characterized by additional human contribution of the Green House gases $\mathrm{CO}_{2}, \mathrm{CH}_{4}, \mathrm{NO}_{\mathrm{x}}$, and others) (Figure 3(d)). It seems to be the first episode in Earth History that a species has had global influence to such an extent on life conditions and relating species extinction.

- Plate Tectonics is mainly directed by magmatic processes in the Earth’s Upper Mantle. Sea level rise and fall interplays with Plate Tectonics which may initiate tsunamis predominantly in the Circum-Pacific and generates the strongest Mega-Volcanic outbreaks at all. Mostly concerned are Cultures on plate margins and con- 
tinental fault zones.

\subsection{Prehistorical/Historical Boundaries Relating to Natural Events}

Most of the relevant boundaries and significant intervals are caused/defined by natural events as follows:

- 14,400 yr B.P: Beginning of early Neolithic Setting in the Near/Middle East (NATUFIAN) relates to Hoyle's Comet (0), an aerosol and an acid event, furthermore on DO-Event 1 , and $\mathrm{CH}_{4}$-Peak indicating increasing temperature.

- 11,500 yr B.P: The Paleolithic/Mesolithic b. in Central Europe coincides with an acid event, droughts in lower latitudes (Red Sea), DO-Event $\mathrm{O}$, and a $\mathrm{CH}_{4}$-peak (temperature rise). This is the end of the Younger Dryas connected with Sea Level Rise, the possible destruction of ATLANTIS, and the interruption of the ABU HUREYRA C., Syria.

- 9600 yr B.P: The probably most catastrophic period throughout Holocene happened in Mid-Mesolithic. It exhibited Hoyle's Comet (3), impact events (tektites), acid events, mass extinction (preferably Large Mammals including Mammoth), temperature decrease (sintwinter), sapropelitic sediments in the Eastern Mediterranean Sea (oxygen deficit). It led to the collapse of all NATUFIAN Cities in Southern Jordan, and correlates with the beginning of RCC 1-Interval when the Cultures of AIN GHAZAL, CATAL HÜYÜK, and CAYÖNÜ began to develop.

- 7500 yr B.P: The Mesolithic/Neolithic b. in Central Europe coincides with Hoyle's Comet (4), several volcanic outbreaks (Hekla), the end of CHAVDAR, KARANOVA C., Bulgaria and LEPENSKI VIR, and the first AHS-import from source areas in the High Balkan Mts. immediately to Central Europe (excavations of EITZUM and ESBECK-1) during glacier retreat.

- 7100-7000 yr Cal. B.P. The Early Middle Neolithic b. can be well defined at Herxheim, West-Germany. Obviously an abrupt drought over Central Europe caused not only a dramatic glacier retreat in the Swiss Alps comparable with our modern situation [6] but triggered the end of agriculture, a general drying up of vegetation, and finally the death of animals both wild and domesticated. This led to cannibalism by HANDKERAMIK PEOPLE applied to lower developed people of "Mesolithic lifestyle" as recognized by boiled fragments of crashed bones and skulls intermixed with pottery shreds, all this through the last decade of Early Neolithic, based on a drought and primarily not on war.

- 6400-6000 yr B.P: The middle /Younger Neolithic b. in Central Europe relates to Hoyle's Comet (5), several volcanic outbreaks (Hekla, Mt. Mazama) that very probably caused sintwinter conditions and glacier advance in the European Alpine Regions. This stopped the AHS-export from Bulgaria to Central Europe. It led to the collapse of local cultures (KARANOVA C.) while north of the Alpine Ranges (Carpathian Mts., Alps) the Younger Neolithic C. continued in a significantly differentiated way. These processes introduced to the RCC 2 interval when, accompanied by reduced solar activity, repeatedly, heavy flooding periods occurred in the Near/Middle East (Mesopotamia) as well as droughts in low latitudes (compare [78]).

- 4800-4600 yr B.P: The Late/End Neolithic b. correlates with Hoyle’s Comet (6) and a Hekla outbreak. This is also the time of King GILGAMESH, the end of Neolithic in Slovakia and Rumania, possibly under influence of volcanic activity and environmental pollution in moderate latitudes as well as the rise of the UGARIT C.

- 4240 yr B.P: End-Neolithic/Early Bronze Age b.

With the beginning of RCC 3 a temperature increase brought drought in lower latitudes (collapse of the AKKADIC C., end of the Old EGYPTIAN KINGDOM). Further glacier retreat allowed access to more ore deposits in alpine regions for the exploitation of $\mathrm{Cu}, \mathrm{Zn}$, Sn, etc.

- 3600 yr B.P: The Early Bronze Age/Hügelgräber Culture b. correlates with the mega-volcanic outbreak of Santorini, Greece and with the end of the MINOAN C. by a tremendous fall-out of pumice ashes and by tsunamis, the HYKSOS invasion, the NEW EGYPTIAN KINGDOM and the JEWS' (ARAMAEIC) MIGRATION to Palestine followed while the MARITIME NATIONS appeared along the East Mediterranean Coast most probably as a result of environmental pollution of their Greek Homeland.

The EL AMARNA C. (ECHNATON), Egypt provides an excellent example for the importance of environmental pollution by mega-volcanism in connection with dramatic social and religious disorder initiated by ejecta (ashes, dust, soot, gases) and restricted solar energy which generated glacier advance in Alpine Regions.

- 3200-3100 yr B.P: The Hügelgräber C./Younger Bronze Age b. coincides with the end of the NEW 
EGYPTIAN KINGDOM and that of the MARITIME NATIONS, all of them correlating with Hoyle's Comet (7) and another HEKLA outbreak under conditions of decreased solar energy and glacier advance preventing further ore exploration in alpine areas.

- 2800 yr B.P: The younger Bronze Age/Pre-Roman Iron Age b. is the time of glacier retreat in alpine regions with improved exploration conditions for ore deposits ( $\mathrm{Cu}, \mathrm{Zn}, \mathrm{Pb}, \mathrm{Sn}, \mathrm{Fe}$, etc...). There occurred the deportation of the JEWS (BABYLONIAN PRISONSHIP), and the amazing coincidence and foundation of PHILOSOPHICAL SYSTEMS and origin of World Religions (Jasper's “ACHSENZEIT”) that indicate ideal life conditions in moderate latitudes ( 700-400 yr B.C).

- 1950 yr B.P $=0$ yr A.D: The Pre-Roman iron Age/Roman Emperor episode b. reveals the end of the PTOLEMAEANS, the origin of CHRISTIANITY and GNOSIS without specific natural events.

- 330 yr A.D: ROMAN EMPIRE/Migration of Nation b. exhibits increasing glacier retreat which provided favorable conditions for overregional MIGRATION.

- 500 yr A.D: The end of Nations Migration/Rise of GERMANIC EMPIRES b. relates to Hoyle's Comet (8) followed by a volcanic and acid event. Further glacier retreat initiated higher mobility and extension. The foundation of the ISLAMIC RELIGION and of the harmonic TANG DYNASTY (Syncretism) took place during this interval that ends with the beginning of RCC 5.

- 710 yr A.D: TEUTONIC and GERMAN EMPIRES/FRANCONIAN EMPIRE b.

The FRANCONIAN EMPIRE mainly covers the RCC 5 interval that ended by a volcanic outbreak.

- 920 yr A.D: The FRANCONIAN EMPIRE/MEDIEVAL EMPIRE b. coincides with the volcanic outbreak at the end of RCC 5 and that of TANG DYNASTY which was a tolerant and constructive episode along the Silk Road (compare Jasper's “ACHSENZEIT”).

- 1060-1250 yr A.D: EMPIRES and PONTIFICATES

A thermal maximum dominates this interval that obviously had a tremendous influence on international aggressive activities like Dschingis Khan's Campaign to Europe, the extension of the HANSE, the SEA TOWNS, the CRUSADERS ENTERPRISES, and the EAST-COLONIZATION. The end of this interval coincides with an acid event and by discovery of the TAUERN GOLD DEPOSITS, Tauern Gold Deposits and the foundation of the THERAVADA BUDDHISTIC PAGODAFIELD AT PAGAN, MYANMAR.

- 1460-1720 yr A.D: "LITTLE GLACIATION" in Central Europe, includes part of Late Middle Ages, ABSOLUTISM, and Age of "ENLIGHTMENT".

This interval comprises the time of RELIGOUS WARS (1500-1670), a volcanic event and TAUERN GOLD EXPLOITATION. Around 1800 yr A.D. the beginning of LIBERALIZATION correlates with two acid events coinciding with the end of RCC 6. Laki Eruption (1783) triggered the French Revolution.

Since $\sim 1890$ yr A.D: we notice rising IMPERIALISM, INDUSTRIALIZATION, CAPITALISM contemporaneously running with significant temperature increase (Figure 3(e)). A dramatic development of SCIENCE and TECHNOLOGY followed, correlating with an increasing number of wars.

Since the sixties of the $20^{\text {th }}$ century, we record growing GLOBALIZATION and a complex interfingering of worldwide problems with exponential temperature rise, damage of Nature and sea level rise (Figure 3(f)).

Finally, it should be stressed that the results of this paper underline the assumption of Clube, Napier, and Hoyle that the natural processes dealt with, do not have only strong influence on Rise and Fall of Cultures but also on SPRITUAL/PSYCHIC EVIDENCE with regard to RELIGION and PHYLOSOPHICAL SYSTEMS. See correlations, thereby we do not absolutely need Hoyle's Comet (9) that is to be re-expected $\sim 2100$ yr A.D, if the other natural processes have another definite source, what we cannot know.

A nice analogy from out the field of CRYSTALLOGRAPHY shows: the higher the formation temperature (thermal energy) of a series of Mixed Crystals, the higher the disorder in the crystal lattice-according to resembling human societies' confusion.

\section{Closing Statement}

"Fred Hoyle’s Aufforderung, solche neuen Denkräume zu betreten, zielt jedoch nicht ins aussenseiterische Abseits, sondern meint die scientific community, zu der Hoyle selbst als ein hoch geachtetes Mitglied gehört. Die Konsequenzen, die Clube/Napier's und Hoyle's Perspektiven eröffneten, wären erheblich. Denn wenn es richtig ist, dass die Lebensverhältnisse der Menschen auf der Erde immer wieder tiefgreifend kosmisch erschüttert worden sind, dann müssen wir die Evolutionsgeschichte des Menschen neu lesen, die 
Menschheitsgeschichte und die Gesellschaftsgeschichte.

Naturgeschichte und Menschheitsgeschichte würden sich viel stärker durchdringen als bisher angenommen, der Ereignisablauf müsste aus den verschiedenen Blickrichtungen der Disziplinen - als ein einziger beschrieben werden. Ein solcher Wechsel in der wissenschaftlichen Wahrnehmung kann von einzelnen und wenigen gefordert und gefördert werden, vollzogen aber wird er vom Streitgespräch der Wissenschaft selbst.”

Eberhard Sens [79]

Hence, this paper presents only a first approach; it makes clear that natural and cultural interrelations are to be more profoundly analyzed by according time-span related specialized scientists.

\section{Acknowledgements}

The authors do very much appreciate the publications of Mayewski et al. [6], Rahmstorf and Schellnhuber [11], Arz et al. [57], Burenhult [25], Koch [26] [72], E. and A. Tollmann [37], Hoyle [9], Clube and Napier [21] [22] who provided a helpful framework for this paper.

\section{References}

[1] Salameh, E., Khoury, H. and Schneider, W. (2006) Jebel Waqf as Suwwan, Jordan, A Possible Impact Crater-A First Approach. Zeitschrift Deutscher Gesellschaft für Geowissenschaften, 157, 319-325. http://dx.doi.org/10.1127/1860-1804/2006/0157-0319

[2] Salameh, E., Khoury, H., Reimold, W.U. and Schneider, W. (2008) The First Large Meteorite Impact Structure Discovered in the Middle East: Jebel Waqf as Suwwan, Jordan. Meteoritics \& Planetary Science, 43, 1681-1690. http://dx.doi.org/10.1111/j.1945-5100.2008.tb00636.x

[3] Salameh, E., Khoury, H., Reimold, W.U., Schneider, W. and Kenkmann, T. (2008) First Large Meteorite Impact Structure Discovered in the Middle East: Jebel Waqf as Suwwan, Jordan. Large Meteorite Impact Planetary IV, Parys, LPI No. 1423, Paper ID: 3106.

[4] Kenkmann, T., Khirfan, M., Reimold, W.U., Salameh, E., Konsul, K. and Khoury, H. (2009) The Structure of Jebel Waqf as Suwwan Impact Crater, Jordan, as Revealed from Field Analysis, Remote Sensing Mapping, and Interpretation of Geophysical Data. The 1st Arab Impact Cratering and Astrogeology Conference, Amman, 9-11 November 2009, Abstract Volume, 32-37.

[5] Schneider, W. and Salameh, E. (2014) Uncommon and Impact-Suspicious Geologic Phenomena across Jordan and Adjacent Area, Arabian Plate. Open Journal of Geology, 4, 680-717. http://dx.doi.org/10.4236/ojg.2014.412051

[6] Mayewski, P.A., Rohling, E.E., Stager, J.C., Karlén, W., Maasch, K.A., Meeker, L.D., et al. (2004) Holocene Climate Variability. Quaternary Research, 62, 243-255. http://dx.doi.org/10.1016/j.yqres.2004.07.001

[7] Schott, A. (1984) Das Gilgamesch-Epos. No. 7235, Philipp Reclam Jun., Stutgart, 122 p.

[8] Jens, W. (1987) Das A und das O. Die Offenbarung des Johannes. Radius-Verlag, Stuttgart, 93 p.

[9] Hoyle, F. (1993) The Origin of the Universe and the Origin of Religion. Moyer Bell, London, 135 p.

[10] Chappellaz, J., Blumier, T., Raynaud, D., Barnola, J.M., Schwander, J. and Stauffert, B. (1993) Synchronous Changes in Atmospheric $\mathrm{CH}_{4}$ and Greenland Climate between 40 and 8 kyr BP. Nature, 236, 443-444. http://dx.doi.org/10.1038/366443a0

[11] Rahmstorf, S. and Schellnhuber, H.J. (2007) Der Klimawandel. 4. Aufl., C.H. Beck, München, 144 p.

[12] Groves, C. (2004) Die Datierung der Vergangenheit. In: Burenhult, G., Ed., Menschen der Urzeit, Karl Müller, Köln, 74-75.

[13] Hammer, C.U., Clausen, H.B. and Dansgaard, W. (1980) Greenland Ice-Sheet Evidence of Post-Glacial Volcanism and Its Climatic Impact. Nature, 288, 230-235. http://dx.doi.org/10.1038/288230a0

[14] Herron, M.M. and Langway Jr., C.C. (1985) Chloride, Nitrate and Sulfate in the Dye 3 and Camp Century, Greenland Ice Cores. In: Langway, C.C., Oeschger, H. and Dansgaard, W., Eds., Greenland Ice Core: Geophysics, Geochemistry, and the Environment, Geophysical Monograph Series, Vol. 33, John Wiley \& Sons, Hoboken, 77-84. http://dx.doi.org/10.1029/gm033p0077

[15] Owen-Smith, N. (1987) Pleistocene Extinctions: the Pivotal Role of Megaherbivores. Paleobiology, 13, $351-362$.

[16] Dubrovo, I. (1990) The Pleistocene Elephants of Sibiria. In: Agenbroad, L.D., Mead, J.I. and Nelson, L., Eds., Megafauna and Man, Northern Arizona University Press, Flagstaf, 1-8.

[17] Chalmers, R.O., Henderson, E.P. and Mason, B. (1976) Occurrence, Distribution, and Age of Australian Tektites. 
Smithsonian Contributions to the Earth Sciences, 17, 1-46. http://dx.doi.org/10.5479/si.00810274.17.1

[18] Phan, C.T. (Ed.) (1990) Geology of Cambodia, Lao and Vietnam. 2nd Edition, Geological Survey of Vietnam, Hanoi, $103 \mathrm{p}$.

[19] Suess, H.E. (1988) Radiocarbon in Tree Rings. In: Castagnoli, G.C., Ed., Solar-Terrestrial Relationships and Earth Environment in the Last Millenia, Societa Italia Fisica, Bologna, 135-143.

[20] Gentner, W. and Wagner, G.A. (1969) Altersbestimmungen an Riesgläsern und Moldaviten. Geologica Bavarica, 61, 296-303.

[21] Clube, V. and Napier, B. (1990) The Cosmic Winter. Blackwell, Oxford.

[22] Napier, W.M. (1989) Terrestrial Catastrophism and Galactic Cycles. In: Clube, S.V.M., Ed., Catastrophes and Evolution, Cambridge University Press, Cambridge, 133-167.

[23] Price, N.J. (2001) Major Impact and Plate Tectonics. Routledge, London, 354 p.

[24] Milankovitch, M. (Ed.) (1930) Mathematische Klimalehre und Astronomische Theorie der Klimaschwankungen. Borntraeger, Berlin.

[25] Burenhult, G. (2004) Radiokarbon-Methode: Schlüssel zur Vergangenheit. In: Burenhult, G., Ed., Menschen der Urzeit, Karl Müller, Köln, 463 p.

[26] Koch, H.P. (2000) Sintflut. Kremayr \& Scheriau, Wien-München, 336 p.

[27] da Costa, K. (2004) Die Natuf-Periode: Anfänge sesshaften Lebens. In: Burenhult, G., Ed., Menschen der Urzeit, Karl Müller, Köln, 234-236.

[28] Liljegren, R. (2004) Tiere der Europäischen Eiszeit. In: Burenhult, G., Ed., Menschen der Urzeit, Karl Müller, Köln, 86-93.

[29] Rowly-Conwy, P. (2004) Abu Hureyra: Die ersten Bauern der Welt. In: Burenhult, G., Ed., Menschen der Urzeit, Karl Müller, Köln, 239-241.

[30] Schöll, M. and Risch, H. (1976) Oxygen- and Carbon Isotope Analysis on Planktonic Foraminifera of Core VA 01-188 P, Southern Red Sea. Geologisches Jahrbuch. Reihe D, 17, 15-32.

[31] Friedman, G.M. (1972) Significance of Red Sea in Problems of Evaporites and Basinal Limestones. AAPG Bulletin, 56, 1072-1086.

[32] Müller, H. and Schleiermacher, F. (1994) Plato, Sämtliche Werke. Timaios, K., et al., Eds., Vol. 4, Rowohlt Enzyklopädie, Reinbek.

[33] Rowly-Conwy, P. (2004) Steinzeitliche Jäger, Sammler und Bauern in Europa- Vom Sammler zum Bauern -und Muschelabfälle: Die Müllhalden der Geschichte. In: Burenhult, G., Ed., Menschen der Urzeit, Karl Müller, Köln, 271-279.

[34] Palmqvist, L. (2004) Der grosse Ubergang. Die ersten Bauern der westlichen Welt. In: Burenhult, G., Ed., Menschen der Urzeit, Karl Müller, Köln, 229-233.

[35] Cheddadi, R., Rossignol-Strick, M. and Fontugne, M. (1991) Eastern Mediterranean Paleoclimates from 26 to 5 ka B.P. Documented by Pollen and Isotopic Analysis of a Core in the Anoxic Bannock Basin. Marine Geology, 100, 53-66. http://dx.doi.org/10.1016/0025-3227(91)90224-R

[36] Surenian, R. (1989) Shock Metamophism in the Koefels Structure, Austria. The 52nd Annual Meetings of the Meteoritical Society, Vienna, 31 July-4 August, 234.

[37] Tollmann, A. and Tollmann, E. (1993) Und die Sintflut gab as doch. Vom Mythos zur Historischen Wahrheit. Droemer Knaur, München, 560 p.

[38] Gebel, H.G.K. (2004) Central to What? The Centrality Issue of the LPPNB Mega-Site Phenomenon in Jordan. In: Bienert, H.-D., Gebel, H.G.K. and Neef, R., Eds., Central Settlements in Neolithic Jordan, Studies in the Early Near Eastern Production, Subsidence, and Environment 5, ex oriente, Berlin, 1-19.

[39] Rollefson, G.O. (2004) Ain Ghazal: Die Grösste Bekannte Neolithsche Siedlung. In: Burenhult, G., Ed., Menschen der Urzeit, Karl Müller, Köln, 248-250.

[40] Palmqvist, L. (2004) Kulte Bei Catal Hüyük. In: Burenhult, G., Ed., Menschen der Urzeit, Karl Müller, Köln, 242-247.

[41] Liljegren, R. (2004) Die Domestizierung von Tieren. In: Burenhult, G., Ed., Menschen der Urzeit, Karl Müller, Köln, 280-287.

[42] Alley, R.B., Mayewski, P.A., Sowers, T., Stuiver, M., Taylor, K.C. and Clark, P.U. (1997) Holocene Climatic Instability: A Prominent Widespread Event 8200 Years Ago. Geology, 25, 483-486. http://dx.doi.org/10.1130/0091-7613(1997)025<0483:HCIAPW>2.3.CO;2

[43] Stäuble, H. (2005) Häuser und Absolute Datierung der Ältesten Bandkeramik. Universitätsforsch. zur Prähistorischen Archäologie, Bd. 117, Bonn, 292 p. 
[44] Dimitrova, E. and Kunov, A. (1974) Petrology of Diabase-Phyllitoid Formation in the Western Balkan Mts. Bulgarian Academy of Sciences, Sofia, 365-378.

[45] Christensen, A.-M., Holm, P.M., Schüssler, U. and Petrasch, J. (2006) Indications of a Major Neolithic Trade Route? An Archaeometric, Geochemical and Sr, Pb-Isotope Study on amphibolithic Raw Material from present Day Europe. Applied Geochemistry, 21, 1635-1655. http://dx.doi.org/10.1016/j.apgeochem.2006.07.009

[46] Prostředink, J., Šida, P., Šrein, V., Šreonova, D. and Štastny, M. (2005) Neolithic Quarrying in the Foothills of the Jizera Mts. and the Dating Thereof. Archeologicke Rodzledy, 57, 477-492.

[47] Schwarz-Mackensen, G. (1983) Die Frühbandkeramische Siedlung Bei Eitsum, LKr. Wolfenbüttel. In: Wegner, G., Ed., Frühe Bauernkulturen in Niedersachsen, Oldenburg, 23-36.

[48] Schneider, W. (2015) Das Rohmaterial Bandkeramischer Felsgesteinsgeräte und Keramik der Grabung Esbeck-1. In: Richter, P.D. and Schwarz-Mackensen, G., Eds., Bandkeramik an der Peripherie. Erdwerk und Siedlung von Esbeck-1 (Stadt Schöningen), Materialhefte zur Ur- und Frühgeschichte Niedersachsen, Bd 45, Marie Leidor GmBH, Rahden/ Westfalen, 323-346.

[49] Schwarz-Mackensen, G. and Schneider, W. (1983) Wo liegen die Hauptliefergebiete für das Rohmaterial Donauländischer Steinbeile und -äxte in Mitteleuropa? Archäologisches Korrespondenzblatt, 13, 305-314.

[50] Schwarz-Mackensen, G. and Schneider, W. (1986) Petrographie und Herkunft des Rohamaterials Neolithischer Steinbeile und -äxte im Nördlichen Harzvorland. Archäologisches Korrespondenzblatt, 16, 29-44.

[51] Schwarz-Mackensen, G. and Schneider, W. (1987) The Raw Material of Neolithic Adzes and Axes in Central Europe: Petrography and Provenance. Antiquity, 61, 66-69.

[52] Schwarz-Mackensen, G. and Schneider, W. (2012) Felsgesteine als Rohmaterial Neolithischer Steinbeile und -äxte in Mitteleuropa. In: Floss, H., Ed., Steinartefakte Vom Altpaläolithikum bis in die Neuzeit, Kerns Verlag, Tübingen, 875892.

[53] Lüning, J. (2000) Steinzeitliche Bauern in Deutschland. Die Landwirtschaft im Neolithikum. Habelt, Bonn.

[54] Todorova, H. (2009) Oral Communication. Bulgaria Academy of Sciences, Sofia.

[55] Fleckinger, A. and Steiner, H. (2005) Der Mann Aus dem Eis. Folio S, Südtiroler Archäologie Museum, Folio Verlag, Bozen, 55 p.

[56] Whitehouse, D. and Whitehouse, R. (1975) Archaeological Atlas of the World. Thames and Hudson, London, 58-59.

[57] Arz, H.W., Haug, G. and Tiedemann, R. (2007) Meeressedimente als Klimaarchiv. Geographische Rundschau, 59, 56-65.

[58] Weblinks: Santorini and Its Eruption in the Late Bronze Age. http://de.wikipedia.org/wiki/MinoischeEruption

[59] TV Report, Pheonix, 17 April 2014.

[60] TV Report, Pheonix, 7 June 2014.

[61] Jaspers, K. (2012) Vom Ursprung und Ziel der Geschichte. 4. Auflage, Fischer Bücherei, Frankfurt a.M., Hamburg, $269 \mathrm{p}$.

[62] Gebhardt (1973) Handbuch der Deutschen Geschichte. Band 1/2, 9. Auflage, dtv Wissenschaftliche Reihe, Deutscher Taschenbuch Verlag, München.

[63] Glasenapp, H. (Ed.) (1957) Die Nichtchristlichen Religionen. Islam, Fischer Bücherei, Frankfurt a.M., 173-193.

[64] Klimkeit, H.-J. (1987) Synkretismus in Zentralasien- eine Zwischenbilanz. In: Heissig, W. and Klimkeit, H.-J., Eds., Synkretismus in den Religionen Zentralasiens, Otto Harrasowitz, Wiesbaden, 207-216.

[65] Stuart, G.S. and Stuart, G.E. (1993) Lost Kingdoms of the Maya. National Geographic Society, Washington, 248 p.

[66] Negendank, J.F.W. (1995) Paläoklima und Aktuelles Klima. In: Hermann von Helmholtz-Gemeinschaft Deutscher Forschungszentren, Hrsg., Paläoklima und Klimaprozesse, Potsdam, 5-7.

[67] Morgenstern, M. (1985) Hildebrand’s Urlaubsführer, China. KG Verlag Gesellschaft, Frankfurt a.M., 111-114.

[68] Schneiderhöhn, H. (1962) Erzlagerstätten. 4. Auflage, Gustav Fischer Verlag, Stuttgart, 371 p. Siehe Auch Geol. Wanderpfad im Nationalpark Hohe Tauren, Rauriser Goldbergbau, Österreich.

[69] Gebhardt (1973) Handbuch der Deutschen Gesechichte. Band 9, 9. Auflage, dtv Wissenschaftliche Reihe, Deutscher Taschenbuch Verlag, München.

[70] Gräber, D. (2011) Debt—The First 5000 Years. Melville House Publishing, Brooklyn, New York, 534 p.

[71] Randers, J. (2012) Eine Globale Prognose für die nächsten 40 Jahre, 2052. Der neue Bericht an den Club of Rome. Oecom Verlag, München, 430 p.

[72] Koch, H.P. (2000) The Diluvian Impact, the Great Flood Catastrophe 10000 Years Ago as the Consequence of a Com- 
et’s Impact. Peter Lang, Wien, Frankfurt a.M., 274 p.

[73] bin Gorion, M.J. (1913) Die Sagen der Juden I. von der Urzeit. XVI, Rütten und Löning, Frankfurt a.M., 378 p.

[74] Gretener, P.E. (1978) Reflexions on the Rare Event and related Concepts in Geology. University of Calgary, Calgary, $17 \mathrm{p}$.

[75] Stöffler, D. (2002) Bedrohung aus dem Weltall—Asteroiden und Kometen. In: Emmermann, R., Balling, R., Hasinger, G., Heiker, F.R., Schütt, C., Walther, D. and Donner, W., Eds., An den Fronten der Forschung: Kosmos-Erde-Leben, S. Hirzel Verlag, Stuttgart, 81-98.

[76] Drewermann, E. (1992) Tiefenpsychologie und Exegese. Vol. 2, Walter Verlag, Olten, Freiburg i. Br., 851 p.

[77] Ellul, J. (1981) Apokalypse. Die Offenbarung der Johannes-Enthüllung der Wirklichkeit. Neukirchener Verlag, Neukirchen-Vluyn, $263 \mathrm{p}$.

[78] Gronenborn, D. (2005) Klimaveränderung und Kulturwandel in Neolithischen Gesellschaften Mitteleuropas. RGZM Tagungen Bd. 1.

[79] Sens, E. (1997) Die unterbrochene Musikstunde. In: Hoyle, F., Ed., Kosmische Katastrophen und der Ursprung der Religion, Insel Verlag, Frankfurt a.M., 135 p. 